\title{
Response of Grazing Land Soil Health to Management Strategies: A Summary Review
}

\author{
Sutie $\mathrm{Xu}{ }^{1, *} \mathbb{C}$, Sindhu Jagadamma ${ }^{1}(\mathbb{D})$ and Jason Rowntree ${ }^{2}$ \\ 1 Department of Biosystems Engineering \& Soil Science, University of Tennessee, 2506 E J Chapman Drive, \\ Knoxville, TN 37996, USA; sjagada1@utk.edu \\ 2 Department of Animal Science, Michigan State University, 474 S. Shaw Lane, East Lansing, MI 48824, USA; \\ rowntre1@msu.edu \\ * Correspondence: sxu24@utk.edu
}

Received: 16 August 2018; Accepted: 12 December 2018; Published: 14 December 2018

\begin{abstract}
Grazing land ecosystem services including food provision and climate regulation are greatly influenced by soil health. This paper provides a condensed review of studies on the response of three important soil properties related to soil health to grazing land management: water infiltration, carbon (C) sequestration, and nitrogen use efficiency (NUE). Impacts of management strategies that are often used in grazing lands are discussed in this review including vegetation composition, grazing methods, and other factors such as fertilizer use and climatic conditions. In general, proper grazing management such as continuous moderate grazing and rotational/deferred-rotational grazing with low or moderate stocking rates tends to benefit all three soil properties. Water infiltration can usually be increased with full vegetation cover, increased soil C, and aggregate stability, or be decreased with greater soil bulk density. Adoption of highly productive plant species with faster turnover rates can promote soil $C$ sequestration by increasing $C$ input. However, excessive $C$ removal from ecosystems due to overgrazing or improper soil fertilization management results in higher $\mathrm{C}$ loss, which can have detrimental effects on soil $C$ sequestration. Proper stocking rate and a balanced manure/fertilizer management was found to be critical for enhancing NUE. Grazing land management sometimes simultaneously influence the three soil properties. Techniques that can increase soil $\mathrm{C}$ such as introduction of high productive plant species can often promote water infiltration and soil nitrogen $(\mathrm{N})$. Some other practices such as adoption of $\mathrm{N}$ fertilizer may enhance $\mathrm{C}$ sequestration while being detrimental to NUE. An integrated management plan for a specific location or farm should be considered carefully to improve soil health as well as ecosystem production. This review provides farmers and policy makers the current state of general knowledge on how health-related soil processes are affected by grazing land management.
\end{abstract}

Keywords: carbon sequestration; water infiltration; nitrogen use efficiency; grazing land management

\section{Introduction}

Grazing lands comprise 3.6 billion ha globally and various management strategies are adopted on these lands to meet the demand for greater productivity and climate resilience [1]. Ecosystem functions such as forage production, nutrient cycling, carbon (C) accumulation, root processes [2-4], and the ecosystem sustainability [5] can be enhanced if a good grazing land management plan is adopted. Grazing management practices can also impact soil properties (e.g., [6]), which play an important role in determining ecosystem productivity and sustainability $[7,8]$. As a result, adopting improved management for building soil health, which is defined as the sustainable ability of soil to function as a vital living ecosystem that can continuously support plants, animals, and humans [9] is critical. Specifically, three important components of soil health including soil water infiltration, C sequestration, 
and nitrogen use efficiency (NUE) present water, carbon, and nutrient dynamics and are strongly influenced by the grazing management practices.

Soil water infiltration, which regulates the ecosystem water cycle and indicates the soil's resistance to erosion, can be influenced by grazing land management (e.g., [10]). When management leads to a decrease in water infiltration, it can cause increased runoff and soil erosion, which are detrimental to ecosystem functions such as livestock productivity [11]. Thus, understanding and improving soil water infiltration is particularly important especially in dry lands [12], which accounts for about $40 \%$ of the global land area $[13,14]$. Past studies investigating the response of soil water infiltration to grazing land management strategies are very few and are often conducted in specific farms or rangelands, which are not representative to the entire grazing lands in the world.

Soil $\mathrm{C}$ regulates nutrient and water supply, soil erosion, and soil physical and chemical properties [15] and can also be strongly influenced by grazing land management (e.g., [16]). Under different management, soil $C$ sequestration can be influenced by changes in both $C$ inputs and outputs. In grazing lands, soil C accumulation accounts for $\sim 90 \%$ of the total ecosystem C [17]. Therefore, a slight change in soil $\mathrm{C}$ in grazing lands can have a large impact on the global $\mathrm{C}$ cycling. Considering the benefits of soil $C$ sequestration on ecosystem functions such as sustaining productivity and mitigating climate change, knowledge on better ways to manage grazing lands is highly needed. However, contradictory results on the response of soil $\mathrm{C}$ to similar grazing land management are often reported.

Nitrogen use efficiency is the ability of plants to use available nitrogen $(\mathrm{N})$, which determines the yield per unit of $\mathrm{N}$ input and can be affected by grazing land management such as plant species (e.g., [18]), fertilizer management (e.g., [19]), and grazing activities (e.g., [20]). Improper management such as overuse of synthetic fertilizers can increase the cost of production as well as $\mathrm{N}$ loss from the ecosystem, which leads to water contamination and greenhouse gas emissions. Thus, improving NUE on grazing lands is essential for both economic and environmental benefits.

Considering the need for achieving the overall impacts of grazing land management towards improved soil health, we reviewed existing refereed manuscripts investigating the changes in infiltration, $C$ sequestration, and NUE by different grazing land management strategies including the vegetation structures (e.g., different grass species, legume incorporation, conversion of forest to pastures, afforestation), grazing methods (e.g., grazing exclusion, grazing intensity, rotational grazing), and other land management approaches (e.g., fertilization, irrigation, prescribed fire) in tandem with climatic and soil factors (Table 1). The goal is to provide the readers a quick and condensed review of the grazing management strategies to improve the sustainability of grazing lands.

Table 1. Grazing land management options influencing the three soil properties surveyed in this review.

\begin{tabular}{|c|c|c|c|}
\hline & Grazing Management & Vegetation Composition & Other Factors \\
\hline Infiltration & $\begin{array}{l}\text { Grazed vs. exclosure } \\
\text { Intensity (heavy vs. } \\
\text { moderate vs. light grazed) } \\
\text { Frequency (continuous vs. } \\
\text { rotational grazed) }\end{array}$ & $\begin{array}{c}\text { Trees/shrubs vs. } \\
\text { bunchgrasses vs. sodgrasses } \\
\text { Grass vs. forbs } \\
\text { Conversion from woodlands } \\
\text { to pastures }\end{array}$ & $\begin{array}{c}\text { Management duration } \\
\text { Topography } \\
\text { Burning } \\
\text { Animal type }\end{array}$ \\
\hline $\begin{array}{c}\text { Carbon } \\
\text { Sequestration }\end{array}$ & $\begin{array}{l}\text { Grazed vs. exclosure } \\
\text { Intensity (heavy vs. } \\
\text { moderate vs. light grazed) } \\
\text { Frequency (continuous vs. } \\
\text { rotational grazed) }\end{array}$ & $\begin{array}{c}\text { Legume incorporation } \\
\text { Conversion from cultivated } \\
\text { lands to pastures } \\
\text { Crop-pasture rotation } \\
\text { Pasture establishment after } \\
\text { deforestation }\end{array}$ & $\begin{array}{c}\text { Fertilization } \\
\text { Irrigation } \\
\text { Burning } \\
\text { Management duration } \\
\text { Soil type } \\
\text { Climate }\end{array}$ \\
\hline $\begin{array}{l}\text { Nitrogen Use } \\
\text { Efficiency }\end{array}$ & $\begin{array}{c}\text { Grazed vs. ungrazed } \\
\text { intensity (heavy vs. } \\
\text { moderate vs. light grazed) }\end{array}$ & $\begin{array}{l}\text { Crop vs. pasture } \\
\text { Legume incorporation } \\
\text { C4 vs. C3 grass }\end{array}$ & Fertilization \\
\hline
\end{tabular}




\section{Methods}

The literature was retrieved in 2017 by searching the Google Scholar using the following search words: "grazing lands/grasslands management," "soil health," "soil water infiltration," "soil C sequestration," and "nutrient/ N use efficiency." No restrictions were imposed for article selections on study locations or the year of publication to prepare this review as long as the articles were written in the English language and focused on grazing land management effects on the three soil properties considered in this review. The reference list of articles used to derive the statements and conclusions in the present review are shown in Appendix A. If there is more than one article with similar conclusions, one or two of the latest ones were cited in the text as example references. The majority of these studies are peer-reviewed articles and books. Study sites reported in the articles were mapped and shown in Appendix B (Figure A1 for soil water, Figure A2 for soil C, and Figure A3 for NUE). If referred articles showed data from a specific country, the coordinates of the corresponding country capital were included in the maps. For comparative analysis of water infiltration, we only selected articles in which the water infiltration rate was given in $\mathrm{cm} \mathrm{hr}^{-1}$ or can be converted to $\mathrm{cm} \mathrm{hr}^{-1}$ (Table 2). The infiltration rate in Table 2 is shown as the percentage of difference between the two management options, which was calculated as:

Percentage of infiltration rate difference $(\%)=($ Management 1 infiltration rate Management 2 infiltration rate)/Management 2 infiltration rate $\times 100 \%$

Articles describing soil $\mathrm{C}$ was selected if the data were in $\mathrm{Mg} \mathrm{C} \mathrm{ha}{ }^{-1}$ or can be converted to $\mathrm{MgC} \mathrm{ha}{ }^{-1}$ (Table 3). The $\mathrm{C}$ sequestration rate after management changes shown in the Table 3 was calculated as:

$$
\begin{gathered}
\mathrm{C} \text { sequestration rate }\left(\mathrm{MgC} \mathrm{ha} \mathrm{yr}^{-1}\right)=(\text { Management } 1 \mathrm{C} \text { content }- \\
\text { Management } 2 \mathrm{C} \text { content }) / \text { years of management }
\end{gathered}
$$

Different parameters associated with NUE were selected from the literature including NUE (\%), $\mathrm{N}$ balance $\left(\mathrm{kg} \mathrm{N} \mathrm{ha}^{-1}\right), \mathrm{N}$ uptake $\left(\mathrm{kg} \mathrm{N} \mathrm{ha}^{-1}\right)$, inorganic $\mathrm{N}\left(\mathrm{mg} \mathrm{N} \mathrm{ha}^{-1}\right)$, and the mineralization rate $\left(\mathrm{mg} \mathrm{N} \mathrm{kg}^{-1} \mathrm{~d}^{-1}\right.$ ) (Table 4). The difference of each parameter between two types of management in Table 4 was calculated as:

Difference in parameters $=$ Management $1-$ Management 2

\section{Soil Water Infiltration}

Soil water infiltration refers to the rate of rainfall or the irrigation water that enters the soil. To sustain soil water infiltration, vegetation cover is critical since it protects soil from high intensity rainfall [21] and improves soil aggregation and other physical properties [22]. Compacted soils negatively influence soil water infiltration rates due to the decreased amount and size of surface pore space [23]. Thus, water infiltration is negatively affected if the vegetation cover is considerably decreased due to intensive grazing $[24,25]$ and/or the soil bulk density is increased by animal trampling [26].

Because of the negative effect of grazing on infiltration rates (e.g., [25]), more recent studies have found that using long-term exclosures can be an effective management strategy to improve hydrological cycling, which can increase water infiltration by $11 \%$ to $132 \%$ (Table 2). Since mismanagement of grazing lands (e.g., overgrazing and undesirable vegetation) can result in soil compaction and water run-off, a balanced livestock management on grazing lands are critical in providing food provisioning to animals while sustaining/improving soil water infiltration and conservation. 
Table 2. Water infiltration rate as affected by grazing land management practices.

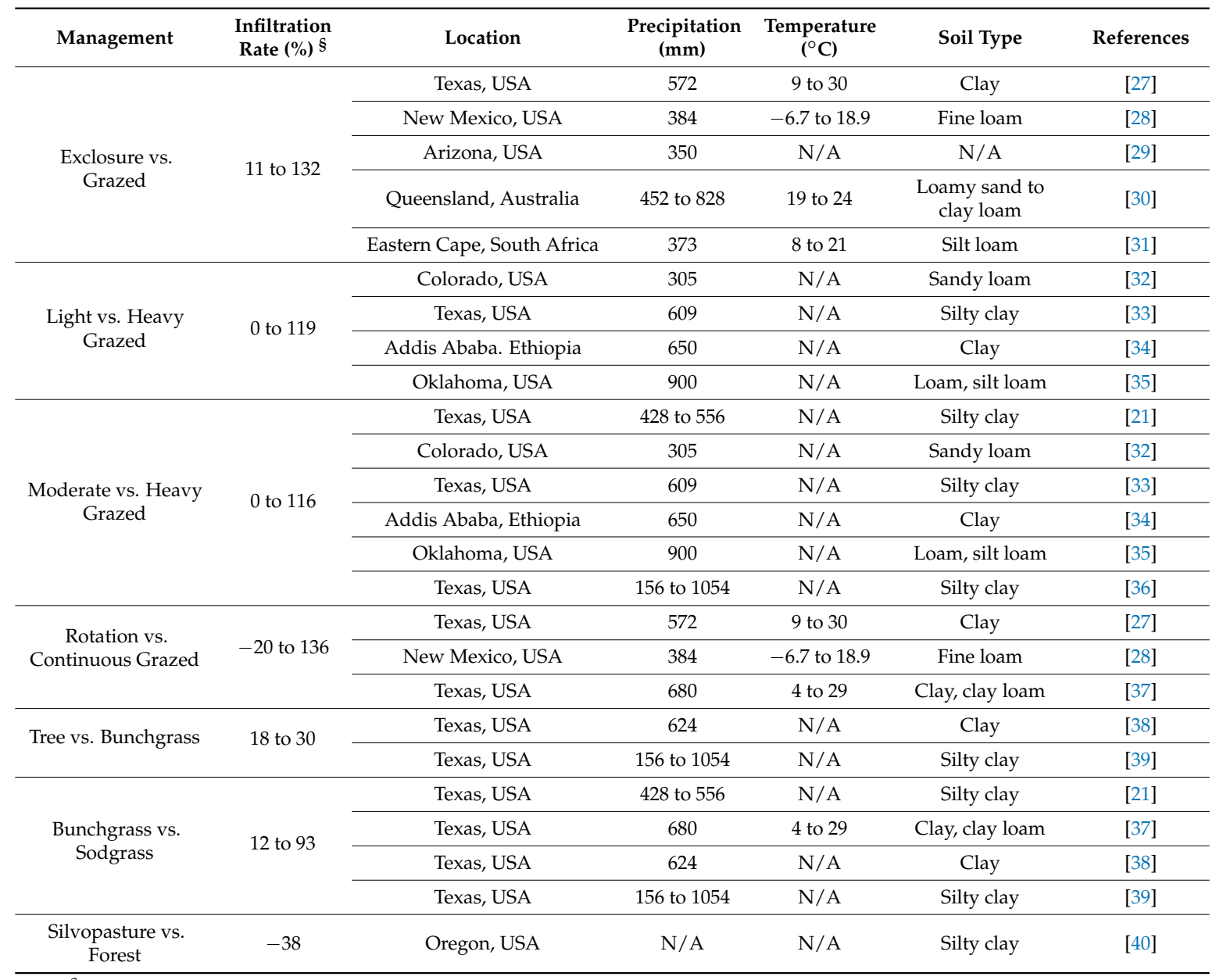

$\S$ The range of difference of first management from second management (e.g., infiltration rate in exclosure is $11 \%$ to $132 \%$ higher than that in grazed areas). N/A means the information is not available from the article.

\subsection{Grazing Intensity and Frequency}

Overgrazing is one of the most common mismanagement of the grazing lands. Besides the negative impacts in terms of soil compaction and loss of vegetation cover, overgrazing may also influence the botanical composition, changing it from long-lived perennials to annuals and forbs resulting in lower productivity [41], and higher land degradation [42]. Thus, adopting appropriate grazing methods can be an effective way to improve soil water infiltration while maintaining livestock productivity. Water infiltration rates can be decreased with higher stocking rates (e.g., [43]) especially with heavy-weight cattle [34]. In contrast, the water infiltration rate under light or moderate grazing can be as high as $119 \%$ greater than that under heavy grazing (Table 2). However, the benefits of decreased stocking rates on water infiltration may only be experienced in soils with higher clay and silt contents because soils with higher sand content are generally not vulnerable to compaction from trampling [34].

Besides adjusting grazing intensity, managing grazing frequency such as rotational grazing can also benefit hydrological properties relative to overgrazing by lowering runoff [44], increasing ground cover [45], and increasing water infiltration [46] to decrease soil erosion and nutrient losses [47]. Specifically, multipaddock grazing [46] and deferred-rotational grazing $[27,38]$ systems were found to benefit water infiltration in some studies. However, the benefit of rotational grazing on infiltration may be offset by higher grazing intensity [35]. The infiltration rates under rotational grazing can be $20 \%$ lower to $136 \%$ higher than continuous grazing (Table 2). This wide variability of the rotational grazing effect on water infiltration in the literature is mainly attributed to the different stocking rates 
used in each ecosystem. In the study [27], the rotational grazing system had $136 \%$ greater infiltration rates than continuous grazed systems despite having similar animal types, study region, vegetation composition, and equal stocking rates ( $\sim 5 \mathrm{ha} / \mathrm{AU})$. However, it should be noted that, in this study, the continuously-grazed system was heavily stocked for 27 years while the rotational grazing system was rotationally grazed for only seven years after 20 years of continuous grazing under a moderate stocking rate $(16.2 \mathrm{ha} / \mathrm{AU})$. The study $[27,28]$ showed that rotational grazing at a heavy stocking rate can have a lower infiltration rate than continuous grazing at a moderate rate. Other factors such as lower precipitation or a higher stocking rate in the sampling area due to the unevenly distributed livestock movements in the rotational grazed area can result in a lower infiltration rate than continuous grazing [28]. These results indicate that management approaches encompassing both proper grazing intensity and frequency are important for improving soil water infiltration and that the grazing methods need to be adjusted according to the specific ecosystem conditions such as climate.

The response of hydrologic processes to grazing methods is influenced by other factors such as management duration [29], topography [34], fire [25], and animal types [12], which are important to consider when determining the grazing intensity and frequency for a specific farm for better water management. For instance, a study on Arizona grasslands observed that grazing exclusion for 54 years had a greater infiltration rate than no-grazing for 25 or 10 years [29]. A study conducted on Ethiopian highlands [34] revealed that proper management such as decreasing the grazing intensity or improving plant cover largely alleviates an adverse effect of grazing in steep than flat lands. Prescribed early fire tended to decrease water infiltration [25] and larger size animals can decrease the water infiltration rate more than smaller size animals such as rabbits and kangaroos [12]. Despite this complexity, the majority of earlier studies have demonstrated that heavy grazing has a detrimental impact on soil water infiltration while light and moderate grazing can be beneficial. Rotational grazing has the potential to improve water infiltration even though this benefit can be nullified if it is associated with heavy grazing.

\subsection{Vegetation Composition}

The vegetation type controls water infiltration rates by influencing soil properties [36]. Water infiltration rates are usually the highest under trees and shrubs $\left(15.1-20 \mathrm{~cm} \mathrm{hr}^{-1}\right)$, which is followed by bunchgrasses $\left(8.4-17 \mathrm{~cm} \mathrm{hr}^{-1}\right)$ and the lowest under sodgrasses $\left(6-13 \mathrm{~cm} \mathrm{hr}^{-1}\right.$ ) (Table 2). It was also shown that the infiltration rate is higher under grass cover than under annual forbs because grass has lower decomposition rates, which may protect the soil from raindrop for a longer time [48]. When both shrub canopy and grass pastures were studied, the grazing effects on water infiltration were not detected [38]. However, the vegetation's impacts are influenced by grazing intensity if only grass pastures are studied. For example, bunchgrass pastures could have lower infiltration rates than sodgrass pastures under heavy grazing conditions [21]. Furthermore, the vegetation cover is the key factor determining water infiltration. One study in Cardigan, Australia found that, if the conversion from native woodlands to managed pastures can increase vegetation cover, it can decrease the runoff by 30\% [49]. Thus, grass species selection in grazing pastures for greater soil water infiltration should also be considered while making a decision on grazing intensities and frequencies.

\section{Soil C Sequestration}

Grazing lands can offset about $20 \%$ of the annual $\mathrm{CO}_{2}$ emitted from land use changes [1]. Therefore, these lands play an important role in mitigating greenhouse gas emission. Soil C sequestration in grazing lands is controlled by above-ground and below-ground plant composition and inputs, $\mathrm{C}$ lost from animal consumption, soil characteristics, $\mathrm{C}$ distribution in labile and stable pools, and litter and root deposition and decomposition rates [50-59]. Management strategies such as adjusting stocking rates to regulate the vegetation utilization rate [16] and adoption of improved grass species or conversion from agricultural lands or woodlands to grasslands would increase $\mathrm{C}$ input and potentially promote soil $\mathrm{C}$ accumulation $[3,60]$. However, since soil $\mathrm{C}$ decomposition rates can also be 
influenced by management, the response of both $C$ input and loss should be evaluated to assess the overall effect of grazing land management on $C$ sequestration.

Based on published studies, the $C$ sequestration rate under improved grazing managements can be from 0 to $4.2 \mathrm{MgC} \mathrm{ha}^{-1} \mathrm{yr}^{-1}$ (Table 3). Earlier reviews on soil C responses to grazing land managements were regional-specific. For example, References [2,3] mainly focused on countries such as Australia, the United Kingdom, New Zealand, Canada, Brazil, and the United States, which encompasses only $26 \%$ of the world's grazing land area. Some other reviews such as Reference [61] considered only one country. However, geographic location was not a factor in selecting articles for the current review. 
Table 3. Soil carbon (C) sequestration as affected by grazing land management practices.

\begin{tabular}{|c|c|c|c|c|c|c|}
\hline Management & $\begin{array}{c}\text { C Sequestration (Mg } \\
\left.\mathrm{Cha}^{-1} \mathrm{yr}^{-1}\right)\end{array}$ & Location & Precipitation (mm) & Temperature $\left({ }^{\circ} \mathrm{C}\right)$ & Soil Type & Reference \\
\hline \multirow{13}{*}{ Exclosure vs. Grazed } & \multirow{13}{*}{-1.5 to 4.2} & Wyoming, USA & 384 & $\mathrm{~N} / \mathrm{A}$ & Sandy loam & [52] \\
\hline & & Wyoming \& Colorado, USA & 366 & N/A & Sandy loam & [54] \\
\hline & & Alberta, Canada & 310 to 500 & N/A & Sand to clay loam & [62] \\
\hline & & Colorado, USA & 325 & N/A & Fine sandy loam & [63] \\
\hline & & Inner Mongolia, China & 366 & 5.1 to 7.7 & Sandy & [64] \\
\hline & & Lanzhou, China & 382 & 6.7 & Sandy loam & [65] \\
\hline & & Wyoming, USA & 200 to 210 & $\mathrm{~N} / \mathrm{A}$ & Sandy loam to clay loam & [66] \\
\hline & & Queensland, Australia & 150 to 500 & $>36$ in summer, $<6$ in winter & Loam, clay, sand & [67] \\
\hline & & Nagqu Prefecture, China & 410 to 480 & -1.2 to -0.6 & Loam to clay & [68] \\
\hline & & Sichuan, China & 749 & -36 to 26 & Silt to loam & [69] \\
\hline & & New South Wales, Australia & 582 & 4 to 18 & Sandy clay & [70] \\
\hline & & Borana rangeland, Ethiopia & 436 & 19 to 26 & Sandy clay loam & [71] \\
\hline & & Borana rangelands, Ethiopia & 238 to 896 & 17 to 28 & Sandy clay loam & [72] \\
\hline \multirow{5}{*}{$\begin{array}{l}\text { Light vs. Heavy } \\
\text { Grazed }\end{array}$} & \multirow{5}{*}{-0.22 to 2.2} & Wyoming, USA & 384 & N/A & Sandy loam & [52] \\
\hline & & Wyoming \& Colorado, USA & 366 & N/A & Sandy loam & [54] \\
\hline & & Sichuan, China & 752 & -10 to 11 & Loam to clay & [73] \\
\hline & & Wyoming, USA & 425 & N/A & Fine loam & [74] \\
\hline & & Inner Mongolia, China & 280 & 3.4 & Loamy sand & [75] \\
\hline \multirow{5}{*}{$\begin{array}{c}\text { Moderate vs. Heavy } \\
\text { Grazed }\end{array}$} & \multirow{5}{*}{-1.4 to 1.8} & North Dakota, USA & $\mathrm{N} / \mathrm{A}$ & $\mathrm{N} / \mathrm{A}$ & Silt loam & [51] \\
\hline & & Sichuan, China & 752 & -10 to 11 & Loam to clay & [73] \\
\hline & & Inner Mongolia, China & 280 & 3.4 & Loamy sand & [75] \\
\hline & & North America (Review) & $\mathrm{N} / \mathrm{A}$ & N/A & N/A & [76] \\
\hline & & North Dakota, USA & 414 & -11 to 21 & Silt loam & [77] \\
\hline \multirow{3}{*}{$\begin{array}{l}\text { Pasture \& Legume } \\
\text { Incorporation vs. } \\
\text { Crop }\end{array}$} & \multirow{3}{*}{0.3 to 1.6} & $\begin{array}{l}\text { Australia, the United Kingdom, New Zealand, } \\
\text { Canada, Brazil and the United State (Review) }\end{array}$ & N/A & N/A & N/A & [2] \\
\hline & & South Dakota, USA & 380 & 13 & Loam, fine sandy loam & [78] \\
\hline & & Goiás, Brazil & 280 to 1500 & 23 & Clay & [79] \\
\hline
\end{tabular}

The range of the $C$ sequestration rate of first management from
$\mathrm{N} / \mathrm{A}$ means the information is not available from the article. 


\subsection{Grazing Intensity and Frequency}

Grazing may decrease soil $C$ input through animal consumption of forages and promotion of $C$ emissions [80]. Grazing activities may decrease soil porosity and increase bulk density $[69,81]$ to limit gas exchange, which can be detrimental to plant production and then negatively affect $C$ accumulation. Hence, a viable strategy for promoting soil $C$ sequestration is grazing exclusion especially for areas under long-term over-grazing history [72,82]. In a study conducted in the Qinghai-Tibetan Plateau, it showed that grazing decreased $33 \%$ soil organic C (SOC) at the top $10 \mathrm{~cm}$ when compared to grazing exclosure for five years [69]. However, based on past studies, grazing exclusion may not always result in soil C sequestration [83] because this practice is often associated with an invasion of forbs or weeds with the shallow root system $[52,84]$. Sometimes grazing adds carbon to the soil by improving plant productivity [85], stimulating tillering [86], promoting compensatory photosynthesis after defoliation [87], and increasing litter incorporation through trampling [58]. The stimulated plant production through grazing can contribute to greater $C$ input, which results in low soil $C$ sequestration under a grazing exclusion $[70,88]$. In addition, grazing can change the vegetation composition through animal diet selection [89], shoot and root $C$ allocation (e.g., [54]), or microbial activities [90], which will influence both the $\mathrm{C}$ input quantity and quality and decomposition rates in different ways. As a result, soil $\mathrm{C}$ stocks can respond positively or negatively to grazing methods. Past studies showed that grazing increased [70], decreased [69], or did not affect [66] soil C stocks when compared to un-grazed or grazing exclusion strategies (Table 3). Thus, the grazing exclusion strategy can benefit soil C sequestration in areas under long-term overgrazing [82] while the effect may not be positive in other locations.

Due to this complexity, adoption of proper grazing methods such as the appropriate grazing intensity and frequency is the key to enhance soil $C$ sequestration while sustaining ecosystem productivity. If the stocking rates were low in the grazed areas, they may have a similar amount of soil $C$ as exclusions $[66,71]$. Several studies indicated that slight or moderate grazing intensity can usually increase aboveground and belowground biomass or plant biodiversity [91-93] or improve soil properties and root dynamics [94], which can promote C sequestration (e.g., [76]). Differently, heavy grazing often decreases soil $\mathrm{C}$ accumulation due to a lower infiltration rate and higher erosion or soil compaction, which can limit plant production $[25,95,96]$. The adoption of light and moderate grazing can sequester as high as $2.2 \mathrm{MgC} \mathrm{ha}^{-1} \mathrm{yr}^{-1}$ more $\mathrm{C}$ compared to heavy grazing (Table 3 ).

Some studies, however, reported increased soil $\mathrm{C}$ content under heavy grazing due to the shift in plant composition such as changing to $\mathrm{C} 4$ grass, which can allocate more below-ground carbon [54]. Thus, it is also possible that the light grazing can lose SOC at a rate of $0.22 \mathrm{MgC} \mathrm{ha}^{-1} \mathrm{yr}^{-1}$ when compared to heavy grazing (Table 3). Despite this, moderate grazing, in general, showed promise for long-term accumulation of soil $C$ due to the favorable effect on biodiversity and plant structure [97].

In contrast to the grazing intensity, rotational grazing can promote $C$ sequestration [98] by increasing plant productivity through a recovery period [99]. For example, grazing increased SOC stocks by $30 \%$ at 0 to $30 \mathrm{~cm}$ than grazing exclusions in a study conducted in New South Wales, which may be due to the promoted root turnover and forage production under grazing because there was 4 to 6 weeks of rest over late spring/summer and late summer/autumn to allow seed set and recruitment. However, some studies reported a decreased effect [100] or no effect of rotational grazing on soil C sequestration [98] due to the interactive effect of other factors such as vegetation composition, climate conditions, fertilizer application, and soil type. Thus, grazing intensity should be adjusted to sustain or improve soil $\mathrm{C}$ sequestration when the rotational grazing method is used.

\subsection{Vegetation Composition}

Adoption of a highly productive plant species with faster turnover rates usually results in higher soil C stocks. For instance, legume incorporation in pasture lands can increase SOC since the legume can promote $\mathrm{N}$ fixation to increase aboveground biomass and soil $\mathrm{C}$ input $[78,101,102]$. Including $\mathrm{C} 4$ grass in C3 grasslands under a warm and humid climate can enhance $\mathrm{C}$ sequestration because 
C4 grass can be more productive under this climate condition and benefit the net ecosystem carbon exchange [103]. Conversion from cultivated lands to pastures [2] or crop-pasture rotations [79] can often exhibit a positive effect on SOC accumulation because of the higher forage litter input.

The conversion of the forest to pasture was also found to increase $C$ sequestration in soils by 0-41\% [104-107] due to the redistribution of more $C$ from aboveground biomass to the soil. Effects of the pasture establishment after clearing the forest of soil C can be influenced by grazing intensity, which can be decreased by $0 \%$ to $26 \%$ if the pastures are under higher stocking rates [108] while it can be increased under low stocking rates [109]. The plant species adopted after afforestation determines the response of soil C. It was found that planting pines in pastures can decrease soil C [110-113] while planting a broadleaf tree can benefit soil $C$ sequestration in native pastures [104].

\subsection{Fertilization, Irrigation, Burning, and Other Factors}

Applying fertilizer on grazing land can improve plant production because nutrients are needed to meet the plant growth demand [114]. At the same time, litter and root production and turnover can be increased to promote soil $C$ sequestration $[50,60,61,115]$. Conversely, ecosystems under limited soil nutrients can decrease $C$ sequestration due to the competition between plant and soil microbes [116-118]. It was also demonstrated that use of organic fertilizers can lead to a higher $C$ sequestration rate than inorganic fertilizers ( $\left.0.82 \mathrm{vs.} 0.54 \mathrm{MgC} \cdot \mathrm{ha}^{-1} \cdot \mathrm{yr}^{-1}\right)$ [3] because of the increase $\mathrm{C}$ input from organic fertilizers. However, organically fertilized systems often have low NUE due to poor management [119]. It was reported that fertilizer inputs decrease soil $C$ in ecosystems with higher initial soil C such as New Zealand dairy farms [120]. A prudent fertilizer management with appropriate selection of the fertilizer type and rate is critical to improve $C$ sequestration.

Together with the fertilizer application, irrigation can also improve soil C [121,122]. It should be noted that the benefit of irrigation on soil C may only be realized in dry areas [50]. Conversely, excess water may decrease soil $C$ accumulation [50] because of higher soil respiration [123] or lower $C$ input (root biomass) to soil $[124,125]$. Moreover, the response of soil $C$ to irrigation sometimes may only be observed under long-term management [122,126].

Soil $\mathrm{C}$ sequestration can be influenced by fire since it can change the plant species composition [127], affect nutrient loss [128,129], and promote $C$ transformation to more stable compounds [130,131]. It was shown that prescribed fire in tandem with light grazing can have little negative or even potentially positive effect on soil C content due to the faster regeneration of improved quality grasses and eventual turning over of such plant inputs to soil C [113].

In reality, grazing land management normally encompasses multiple and inter-related management strategies. For example, the impacts of vegetation on $C$ sequestration may be influenced by grazing intensity [132]. In addition, although higher stocking rates are not desirable, combining it with fertilization may promote $C$ accumulation [133]. Therefore, it is important to consider all management options collectively to evaluate the soil $C$ response.

A multitude of other factors such as the duration of management [72], soil type [134], and climate [94] can alone or interactively influence how soil $C$ accumulation respond to grazing management. For example, the soil $C$ change can be a slow process [135] or it can be increased within a few years after imposing the management and reaching an equilibrium [136]. According to Reference [122], irrigation, legume incorporation, grassland establishment, and earthworm introduction enhance $C$ sequestration within 10 years while a longer-time scale of 20 to 40 years is needed to detect changes in soil $\mathrm{C}$ from management such as plant species conversion, fertilizer application, or grazing. It was revealed that clay soils under high precipitation and heavy grazing can be more vulnerable to soil erosion [137] and soil C loss compared to sandy soils [138]. In addition, similar to irrigation, excessive rainfall $(>3000 \mathrm{~mm})$ may increase soil erosion and decrease soil C [104] which could be more serious under grazing [56]. Thus, these factors should be considered when developing the best grazing land management strategies for long-term soil C sequestration. 


\section{Nitrogen Use Efficiency}

Nitrogen use efficiency often refers to the proportion of the $\mathrm{N}$ exports from the ecosystem of $\mathrm{N}$ imports to the ecosystem [139]. The global NUE is low in animal production systems ( 10\%) [140] because a large amount of $\mathrm{N}$ is lost through emissions and leaching [141]. Based on past studies, the NUE of feed ranges from $16 \%$ to $36 \%$, manure/fertilizer ranges from $16 \%$ to $77 \%$, and the entire dairy farm ranges from $8 \%$ to $64 \%$ [141]. These broader ranges indicate that there is a great potential to improve NUE and it is critical to promote the plant's ability to utilize nutrients or to increase nutrient availability for production. In earlier studies, the $\mathrm{N}$ surplus (difference between $\mathrm{N}$ inputs and outputs) was also often used to evaluate the $\mathrm{N}$ loss [142,143], which can provide similar information as the directly measured NUE. Beyond that, some other measurements, as indicated in Table 4, are also used to evaluate NUE.

Table 4. Nutrient use efficiency as affected by grazing land management practices.

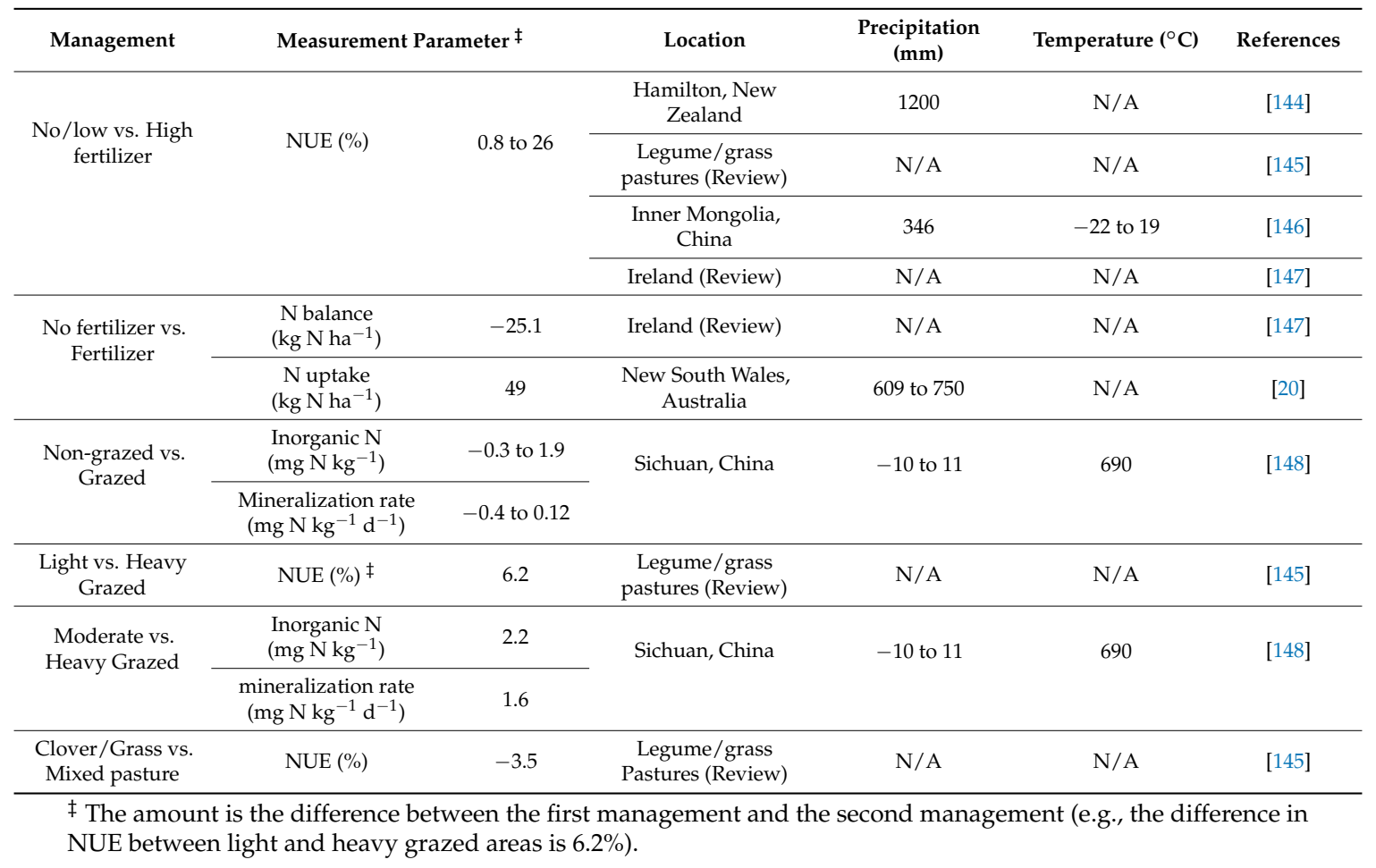

To improve the NUE in grazing lands, strategies such as lowering the stocking rate on overgrazed farms, promoting plant production, managing animal manure efficiently, providing $\mathrm{N}$ feed based on animals' needs, decreasing synthetic $\mathrm{N}$ application, using low-protein high-energy feed, or introducing legumes are recommended [140,144].

\subsection{Grazing Intensity}

Grazing can benefit soil $\mathrm{N}$ cycling by facilitating litter decomposition, increasing $\mathrm{N}$ availability (e.g., [90]), promoting $\mathrm{N}$ mineralization in excreta, decreasing $\mathrm{N}$ immobilization [120], or enhancing soil microbial activities [149]. The $\mathrm{N}$ dynamics were shown to be promoted under grazing with greater $\mathrm{N}$ accumulation at $0-30 \mathrm{~cm}$ soil depth [52]. Livestock integration on row production systems can also benefit $\mathrm{N}$ dynamics by enhancing $\mathrm{N}$ mineralization and plant assimilation [120] or affecting crop development to realize greater production [20]. However, heavy grazing may be detrimental to $\mathrm{N}$ cycling since it can cause a loss of more nitrate $\mathrm{N}$ due to the higher urinary $\mathrm{N}$ [150] and may decrease the soil $\mathrm{N}$ mineralization rate [148]. Nevertheless, moderate grazing was found to benefit $\mathrm{N}$ cycling. A study in Sichuan, China detected that the non-grazed area had $1.9 \mathrm{mg} \mathrm{N} \mathrm{kg}^{-1}$ more inorganic $\mathrm{N}$ 
than a heavy grazed area while it was $0.3 \mathrm{mg} \mathrm{N} \mathrm{kg}^{-1}$ lower than the moderately grazed area [148] (Table 4). The similar trend was also found in the $\mathrm{N}$ mineralization rate in this study.

\subsection{Vegetation Composition}

Vegetation species can influence $\mathrm{N}$ cycling through different $\mathrm{N}$ fixation abilities or root activities. It was reported that plant species, which exhibit higher $\mathrm{N}$ utilization by animals and higher $\mathrm{N}$ uptake from soil will increase NUE [145]. Including legumes in grasslands can increase the N yield [151] and improve efficiency of the conversion of forage into animal products due to the enhanced nutritive value and voluntary intake [152]. It was also found that clover-ryegrass mixtures exhibit higher NUE compared to pure clover or ryegrass pastures [153] and deep-rooted perennial species showed increased NUE due to increased resiliency to weather fluctuations [145]. It was demonstrated that C4 grasses show higher NUE since they release N slowly belowground due to lower litter quality compared to C3 grasses [154].

\subsection{Fertilization}

A synthetic $\mathrm{N}$ fertilizer is often applied on grazing lands to increase plant productivity. However, a major part of the $\mathrm{N}$ input is lost to the environment. Higher $\mathrm{N}$ fertilizer application increases $\mathrm{NH}_{3}-\mathrm{N}$ loss and $\mathrm{N} \%$ in animal urine [155], which could result in decreased NUE ranging from $0.8 \%$ to $26 \%$ compared to un-fertilized or lower fertilized grazing lands (Table 4). As in the case of other management, the fertilizer's effect may be influenced by other factors such as the stocking rate and climate [147].

Manure management and application are also critical to increase NUE especially for smallholder farms [156]. It was shown that the NUE in African crop-livestock integrated systems with limited resources for manure handling is between $6 \%$ and $99 \%$ and, for manure storage, it is between $30 \%$ and $87 \%$ [157], which indicates great potential to increase whole farm NUE through manure management.

\subsection{Fire}

Fire can decrease the quantity of above ground biomass while it may benefit the $\mathrm{N}$ dynamics by promoting $\mathrm{N}$ fixation because of the increased temperature [158]. Burning can result in more available light, less litter cover, and higher $\mathrm{N}$ immobilization in roots $[159,160]$. However, the benefit of fire on NUE usually only happens when fires are short-term since long occurring fires will decrease the litter quality, which will decrease soil organic $\mathrm{N}$ and available $\mathrm{N}$ [158].

\section{Interplay between Soil Moisture, C, and Nutrient Dynamics}

In some cases, grazing land management practices simultaneously influence soil moisture, $\mathrm{C}$, and nutrient dynamics [26]. It was suggested that one of the important factors controlling the water infiltration rate is soil organic matter since it can enhance the soil resistance to the raindrop impact [21,25]. Thus, the water infiltration rate can be enhanced if the soil organic matter is increased by changing grazing intensities [28]. A study in north Texas tall grass prairie indicated that adoption of moderate grazing can not only increase SOC but also soil aggregate stability and fungal/bacterial ratio, which ultimately benefit the hydrologic process, nutrient availability, and retention [22]. Water infiltration is also closely related to NUE as the lower infiltration usually results in greater runoff, which will increase soil erosion and nutrient losses [46]. Improper management such as overgrazing and prescribed early fire can be detrimental to nutrient availability, aggregate structure, and the infiltration rate [25].

Soil $\mathrm{C}$ and $\mathrm{N}$ often exhibit a similar response to grazing management. For example, both soil C and $\mathrm{N}$ increase under a proper grazing intensity or frequency compared to overgrazing [161,162]. Even under intensive grazing, soil $\mathrm{C}$ and $\mathrm{N}$ can be increased with the incorporation of highly productive $\mathrm{C} 4$ grass and with $\mathrm{N}$ fertilization [163]. A study in resource-poor Africa grazing lands also suggested that both SOC and NUE can be improved under manure application and management [157]. 
Conversely, some management such as irrigation in non-arable areas may promote nutrient leaching and decomposition of soil organic matter and decrease the root biomass, which will result in lower soil C and N [164]. Sometimes adoption of specific management may lead to a diverse response of different soil properties. Synthetic $\mathrm{N}$ fertilizer application, for instance, can improve $\mathrm{C}$ sequestration in many cases [3] due to the improved forage productivity and $\mathrm{C}$ input while it often diminishes the NUE in grazing lands (Table 4).

\section{Research Gaps}

Despite the importance of water, $\mathrm{C}$ and $\mathrm{N}$ dynamics on soil health, the impact of grazing land management on water infiltration, and NUE were much less studied than $C$ sequestration. The number of literature we found on soil $C$ sequestration was three times more than that for water infiltration and NUE ( 120 vs. 40). Studies on soil water infiltration responding to different grazing land management is geographically limited and the temporal effect is also not well understood. Although a lot of studies focused on soil $C$ sequestration, there are still many uncertainties such as the mechanisms of soil $\mathrm{C}$ cycling, the climate effects, the response of deeper soils, the dynamics of soil inorganic $\mathrm{C}$, and region-specific management strategies. Many studies on NUE were conducted on dairy farms. However, how to better manage these farms to limit N loss is still unclear. Moreover, other grazing lands besides dairy farms should also be investigated. In addition, the use of new approaches based on microbial analysis and modeling on NUE studies are rare.

\section{Conclusions}

Grazing land management strategies such as the change of vegetation composition, grazing intensity and duration, fertilizer use, irrigation, and fire can affect soil processes pertaining to healthy soil. Adoption of plant species with higher productivity and light or moderate grazing are desirable strategies to improve overall soil health. However, grazing land management often encompasses multiple practices, which can interactively influence soil health positively or negatively. Furthermore, factors such as grazing duration, climate, and soil type can also influence the impacts of grazing land management on soil properties. This review points to the need for more studies to establish regional-specific best grazing land management practices that support long-term soil health.

Author Contributions: S.X. literature and data collection, writing original draft, and editing; S.X., J.R., and S.J., funding acquisition, methodology, writing, and revising.

Funding: This literature review work is funded by Soil Health Literature and Information Review Grants by the Soil Health Institute (Grant number - PD 26238). A final report with a complete literature review and citations is submitted to the Soil Health Institute. The work was also partially supported by USDA National Institute of Food and Agriculture Grant Number: 2017-51106-27003.

Conflicts of Interest: The authors declare no conflict of interest. 


\section{Appendix A}

Table A1. Papers associated with the effects of grazing land management on soil water infiltration.

\begin{tabular}{|c|c|c|c|}
\hline Author name & Journal/Book name & Year, volume, page\# & Note \\
\hline Abdel-Magid et al. & Journal of Range Management & $1987,307-309$ & \\
\hline Bharati et al. & Agroforestry systems & $2002,56(3), 249-257$ & \\
\hline Blackburn & Water Resources Research & $1975,11(6), 929-937$ & \\
\hline Castellano \& Valone & Journal of Arid Environments & $2007,71(1), 97-108$ & \\
\hline Coughenour & Journal of Range Management & $1991,44(6), 530-542$ & \\
\hline Dadkhah \& Gifford & Journal of the American Water Resources Association & $1980,16(6), 979-986$ & \\
\hline Daniel et al. & Transactions of the ASAE & $2002,45(6), 1911$ & \\
\hline Eldridge et al. & Ecological Applications & $2016,26(4), 1273-1283$ & G \\
\hline Fraser \& Stone & The Rangeland Journal & $2016,38(3), 245-259$ & \\
\hline Gamougoun et al. & Journal of Range Management & $1984,538-541$ & \\
\hline Gilley et al. & Applied engineering in agriculture & $1996,12(6), 681-684$ & \\
\hline GR McCalla et al. & Journal of Range Management & $1984,265-269$ & \\
\hline Greenwood \& McKenzie & Australian Journal of Experimental Agriculture & $2001,41(8), 1231-1250$ & \\
\hline Haan et al. & Rangeland Ecology \& Management & $2006,59(6), 607-615$ & G \\
\hline Hillel & Book Introduction to environmental soil physics & 2003 & Book \\
\hline Linnartz et al. & Journal of Forestry & $1966,64(4), 239-243$ & \\
\hline McGinty et al. & Journal of Range Management & $1979,33-37$ & \\
\hline McIvor et al. & Australian Journal of Experimental Agriculture & $1995,35(1), 55-65$ & \\
\hline Moyo et al. & African Journal of Range \& Forage Science & $1998,15(1-2), 16-22$ & \\
\hline Mwendera \& Saleem & Soil Use and Management & $1997,13(1), 29-35$ & G \\
\hline Naeth \& Chanasyk & Journal of Range Management & $1995,528-534$ & \\
\hline Park et al. & Journal of Soil and Water Conservation & $2017,72(2), 102-121$ & G \\
\hline Pluhar et al. & Journal of Range Management & $1987,240-243$ & \\
\hline Proffitt et al. & Australian Journal of Agricultural Research & $1993,44(2), 317-331$ & \\
\hline Rauzi \& Smith & Journal of Range Management & $1973,126-129$ & \\
\hline Rietkerk et al. & Plant Ecology & 2000,148 (2), 207-224 & \\
\hline Russell et al. & Journal of Range Management & $2001,184-190$ & \\
\hline Sanjari et al. & Soil Research & 2010, 47 (8), 796-808 & \\
\hline Savadogo et al. & Agriculture, Ecosystems \& Environment & 2007, $118(1-4), 80-92$ & G \\
\hline Takar et al. & Journal of Range Management & $1990,486-490$ & \\
\hline Teague et al. & Agriculture, Ecosystems \& Environment & $2011,141(3-4), 310-322$ & \\
\hline Thurow et al. & Journal of Range Management & $1986,505-509$ & \\
\hline Thurow et al. & Journal of Range Management & $1988,296-302$ & \\
\hline Van Haveren & Journal of Range Management & $1983,586-588$ & \\
\hline Vandandorj et al. & Ecohydrology & $2017,10(4), \mathrm{e} 1831$ & G \\
\hline Warren et al. & Journal of Range Management & $1986,486-491$ & \\
\hline Warren et al. & Journal of Range Management & $1986,500-504$ & \\
\hline Weltz \& Wood & Journal of Range Management & $1986,365-368$ & \\
\hline West et al. & Rangeland Ecology \& Management & $2016,69(1), 20-27$ & \\
\hline Wood \& Blackburn & Journal of Range Management & $1981,331-335$ & \\
\hline Yisehak et al. & Journal of arid environments & $2013,98,70-78$ & \\
\hline
\end{tabular}

Notes: Articles related to several ecosystem functions including water infiltration are marked as " $\mathrm{G}$ " and books are marked as "Book" in the "Note" column. 
Table A2. Papers associated with the effects of grazing land managements on soil carbon sequestration.

\begin{tabular}{|c|c|c|c|}
\hline Author name & Journal name & Year, volume, page\# & Note \\
\hline Alemu et al. & Journal of Animal Science & $2017,95,145-146$ & \\
\hline Allard et al. & Agriculture, Ecosystems \& Environment & $2007,121(1-2), 47-58$ & \\
\hline Ardö \& Olsson & Journal of Arid Environments & $2003,54(4), 633-651$ & \\
\hline Asner et al. & Global Change Biology & $2004,10(5), 844-862$ & \\
\hline Aynekulu et al. & Geoderma & $2017,3071-7$ & \\
\hline Bagchi et al. & Agriculture, Ecosystems \& Environment & $2017,239199-206$ & G \\
\hline Balogh et al. & Cereal Research Communications & $2005,33(1), 149-152$ & \\
\hline Bardgett \& Wardle & Ecology & $2003,84(9), 2258-2268$ & \\
\hline Berthrong et al. & Ecological Applications & $2009,19(8), 2228-2241$ & \\
\hline Bikila et al. & Agriculture, Ecosystems \& Environment & 2016, 223 108-114 & \\
\hline Bowden et al. & Forest Ecology and Management & $2004,196(1), 43-56$ & \\
\hline Bremer et al. & Environmental Conservation & $2016,43(4), 397-406$ & \\
\hline Brewer & $\begin{array}{l}\text { Influences of fuel moisture and repeated burning on } \\
\text { black carbon production and loss in masticated fuels: } \\
\text { An experimental combustion study. }\end{array}$ & 2012 & Thesis \\
\hline Briggs et al. & AIBS Bulletin & $2005,55(3), 243-254$ & G \\
\hline Briske \& Richards & $\begin{array}{l}\text { Wildland plants: physiological ecology and } \\
\text { developmental morphology }\end{array}$ & $1995,635-710$ & Book \\
\hline Burke et al. & $\begin{array}{l}\text { Biogeochemistry of managed grasslands in central } \\
\text { north america }\end{array}$ & $1997,85-98$ & G, Book \\
\hline Buytaert et al. & Catena & $2007,70(2), 143-154$ & \\
\hline Carvalho et al. & Soil and Tillage Research & $2010,110(1), 175-186$ & $\mathrm{~N}$ \\
\hline Carvalho et al. & Agriculture, Ecosystems \& Environment & 2014,183 167-175 & \\
\hline Chan et al. & Soil Research & $2010,48(1), 7-15$ & \\
\hline Chen et al. & Scientific reports & 2015,510892 & \\
\hline Chimner \& Welker & Pastoralism: Research, Policy and Practice & $2011,1(1), 20$ & \\
\hline Conant et al. & Ecological Applications & $2017,27(2), 662-668$ & \\
\hline Conant \& Paustian & Global Biogeochemical Cycles & $2002,16(4)$ & \\
\hline Conant et al. & Ecological Applications & $2001,11(2), 343-355$ & \\
\hline Conrad et al. & Agriculture, Ecosystems \& Environment & $2017,24838-47$ & \\
\hline Cui et al. & Ecological Research & $2005,20(5), 519-527$ & \\
\hline de Figueiredo et al. & Journal of Cleaner Production & $2017,142420-431$ & \\
\hline De Rose & Earth Surface Processes and Landforms & $2013,38(4), 356-371$ & \\
\hline Derner et al. & Plant and Soil & $1997,191(2), 147-156$ & \\
\hline Detling et al. & Oecologia & $1979,41(2), 127-134$ & \\
\hline Doescher et al. & Journal of Range Management & $1997,285-289$ & \\
\hline Don et al. & Global Change Biology & $2011,17(4), 1658-1670$ & \\
\hline Dormaar et al. & Journal of Range Management & $1977,195-198$ & \\
\hline Dormaar et al. & Journal of Range Management & $1997,647-651$ & \\
\hline Dyer \& Bokhari & Ecology & $1976,57(4), 762-772$ & \\
\hline Eclesia et al. & Global Change Biology & $2012,18(10), 3237-3251$ & \\
\hline Elmore \& Asner & Global Change Biology & $2006,12(9), 1761-1772$ & \\
\hline Fearnside \& Barbosa & Forest Ecology and Management & $1998,108(1-2), 147-166$ & \\
\hline Feyisa et al. & Catena & $2017,1599-19$ & \\
\hline Follett \& Reed & Rangeland Ecology \& Management & $2010,63(1), 4-15$ & \\
\hline Fontaine et al. & Ecology letters & $2004,7(4), 314-320$ & \\
\hline Frank et al. & Journal of Range Management & $1995,470-474$ & \\
\hline Frank et al. & Ecology & $2002,83(3), 602-606$ & \\
\hline $\begin{array}{l}\text { Frank \& } \\
\text { McNaughton }\end{array}$ & Oecologia & $1993,96(2), 157-161$ & \\
\hline $\begin{array}{l}\text { Franzluebbers \& } \\
\text { Stuedemann }\end{array}$ & Agriculture, Ecosystems \& Environment & $2009,129(1-3), 28-36$ & \\
\hline Giardina et al. & Oecologia & $2004,139(4), 545-550$ & \\
\hline González-Pérez et al. & Environment international & $2004,30(6), 855-870$ & G \\
\hline Grünzweig et al. & Global Change Biology & $2003,9(5), 791-799$ & \\
\hline Guo \& Gifford & Global Change Biology & $2002,8(4), 345-360$ & \\
\hline He et al. & Ecosphere & $2011,2(1), 1-10$ & \\
\hline Hewitt et al. & Soil Use and Management & $2012,28(4), 508-516$ & \\
\hline Hiernaux et al. & Journal of Arid Environments & $1999,41(3), 231-245$ & G \\
\hline Hik \& Jefferies & The Journal of Ecology & $1990,180-195$ & G \\
\hline
\end{tabular}


Table A2. Cont.

\begin{tabular}{|c|c|c|c|}
\hline Author name & Journal name & Year, volume, page\# & Note \\
\hline Houlbrooke et al. & Soil Use and Management & $2008,24(4), 416-423$ & \\
\hline Hunt \& Phillips & Biogeosciences & 2016, 13 (10), 2927 & $\mathrm{~N}$ \\
\hline Ingram et al. & Soil Science Society of America Journal & $2008,72(4), 939-948$ & \\
\hline Jastrow et al. & Climatic Change & $2007,80(1-2), 5-23$ & \\
\hline Jobbágy \& Jackson & Ecological Applications & $2000,10(2), 423-436$ & \\
\hline Jones \& Donnelly & New Phytologist & $2004,164(3), 423-439$ & \\
\hline Kallenbach et al. & Nature communications & 2016,713630 & \\
\hline Kang et al. & Journal of Soils and Sediments & $2013,13(6), 1012-1023$ & \\
\hline Kauffman et al. & Oecologia & $1995,104(4), 397-408$ & \\
\hline Kelliher et al. & Agriculture, Ecosystems \& Environment & $2012,14829-36$ & \\
\hline Kelliher et al. & New Zealand Journal of Agricultural Research & $2015,58(1), 78-83$ & \\
\hline Khan et al. & Journal of Environmental Quality & $2007,36(6), 1821-1832$ & \\
\hline Kirschbaum et al. & Forest Ecology and Management & $2008,255(7), 2990-3000$ & \\
\hline Kirschbaum et al. & Science of the Total Environment & $2017,57761-72$ & \\
\hline Knicker & Biogeochemistry & $2007,85(1), 91-118$ & \\
\hline Kuhry & Journal of Ecology & $1994,899-910$ & \\
\hline Lal & $\begin{array}{l}\text { Soil Conservation and Management inthe Humid } \\
\text { Tropics; Proceedings of theInternational Conference }\end{array}$ & 1977 & Conference \\
\hline Lal & Annals of Arid Zone & $2000,39(1), 1-10$ & G \\
\hline Lal \& Follett & Soil carbon sequestration and the greenhouse effect. & 2009 & Book \\
\hline Li et al. & New Zealand Journal of Agricultural Research & $2008,51(1), 45-52$ & \\
\hline Liebig et al. & Agriculture, Ecosystems \& Environment & $2006,115(1-4), 270-276$ & \\
\hline Liu et al. & PloS one & 2012,7 (5), e36434 & \\
\hline Ma et al. & Ecological Engineering & $2016,87203-211$ & G \\
\hline Maia et al. & Geoderma & $2009,149(1-2), 84-91$ & \\
\hline Manzoni et al. & Ecological Monographs & $2010,80(1), 89-106$ & \\
\hline Martınez \& Zinck & Soil and Tillage Research & $2004,75(1), 3-18$ & \\
\hline McNally et al. & Plant and Soil & $2015,392(1-2), 289-299$ & \\
\hline McNaughton & The American Naturalist & $1979,113(5), 691-703$ & G \\
\hline McSherry \& Ritchie & Global Change Biology & $2013,19(5), 1347-1357$ & \\
\hline Medina-Roldán et al. & Agriculture, Ecosystems \& Environment & $2012,149118-123$ & \\
\hline Meersmans et al. & Global Change Biology & $2009,15(11), 2739-2750$ & \\
\hline Miller & Soils: An introduction to soils and plant growth. & 1990 & Book \\
\hline Moinet et al. & Geoderma & $2016,27468-78$ & \\
\hline Moinet et al. & Science of the Total Environment & $2017,5791715-1725$ & \\
\hline Mortenson et al. & Environmental Management & 2004, 33 (1), S475-S481 & \\
\hline Naeth et al. & Journal of Range Management & $1991,7-12$ & G \\
\hline Navarrete et al. & Global Change Biology & $2016,22(10), 3503-3517$ & G \\
\hline Orgill et al. & Land Degradation \& Development & $2018,29(2), 274-283$ & \\
\hline Parfitt \& Ross & Soil Research & $2011,49(6), 494-503$ & \\
\hline Piñeiro et al. & Global Biogeochemical Cycles & $2009,23(2)$ & \\
\hline Pineiro et al. & Global Change Biology & $2006,12(7), 1267-1284$ & G \\
\hline Powers \& Veldkamp & Biogeochemistry & $2005,72(3), 315-336$ & \\
\hline Reeder et al. & $\begin{array}{l}\text { The potential of US grazing lands to sequester } \\
\text { carbon and mitigate the greenhouse effect. }\end{array}$ & $2001,139-166$ & G, Book \\
\hline Reeder \& Schuman & Environmental pollution & $2002,116(3), 457-463$ & G \\
\hline Reeder et al. & Environmental Management & 2004, $33(4), 485-495$ & \\
\hline Rong et al. & Agriculture, Ecosystems \& Environment & 2017,237 194-202 & G \\
\hline Rufino et al. & Livestock Science & $2007,112(3), 273-287$ & $\mathrm{~N}$ \\
\hline Sanderman et al. & PloS one & $2015,10(8), \mathrm{e} 0136157$ & G \\
\hline Sanjari et al. & Soil Research & $2008,46(4), 348-358$ & \\
\hline Schipper et al. & Soil Science Society of America Journal & 2013, 77 (1), 246-256 & \\
\hline Schipper et al. & New Zealand Journal of AgriculturalResearch & $2017,60(2), 93-118$ & \\
\hline Schipper et al. & Agriculture, Ecosystems \& Environment & $2010,139(4), 611-617$ & \\
\hline Schipper \& Sparling & Biogeochemistry & $2011,104(1-3), 49-58$ & \\
\hline Schulz et al. & Forest Ecology and Management & $2016,36762-70$ & \\
\hline Schuman et al. & Ecological Applications & $1999,9(1), 65-71$ & $\mathrm{~N}$ \\
\hline Stahl et al. & Regional environmental change & $2016,16(7), 2059-2069$ & \\
\hline Steffens et al. & Geoderma & $2008,143(1-2), 63-72$ & \\
\hline Stiles et al. & Science of the Total Environment & $2017,593688-694$ & \\
\hline Talore et al. & Journal of the Science of Food andAgriculture & $2016,96(6), 1945-1952$ & \\
\hline
\end{tabular}


Table A2. Cont.

\begin{tabular}{lll}
\hline Author name & Journal name & Year, volume, page\# \\
\hline Wang et al. & Agriculture, Ecosystems \& Environment & 2016,232 290-301 \\
Wang \& Houlton & Geophysical Research Letters & $2009,36(24)$ \\
Wei et al. & Journal of soil science and plant nutrition & $2011,11(4), 27-39$ \\
Witt et al. & Agriculture, Ecosystems \& Environment & $2011,141(1-2), 108-118$ \\
Wright et al. & Soil Biology and Biochemistry & $2004,36(11), 1809-1816$ \\
Wu et al. & Journal of Environmental Quality & $2008,37(2), 663-668$ \\
Xiong et al. & Chinese geographical science & $2014,24(4), 488-498$ \\
Xiong et al. & Ecological Engineering & $2016,94647-655$ \\
Xu et al. & Plant and Soil & $2016,399(1-2), 233-245$ \\
Su et al. & Catena & $2005,59(3), 267-278$ \\
\hline
\end{tabular}

Notes: Articles related to several ecosystem functions including carbon sequestration are marked as " $\mathrm{G}$ " in the

"Note" column. Articles related to both carbon sequestration and nitrogen use efficiency are marked as "N" in the

"Note" column. Books, thesis and conference paper are marked as "Book", "Thesis" and "Conference", respectively, in the "Note" column.

Table A3. Papers selected associated with the effects of grazing land managements on nitrogen use efficiency.

\begin{tabular}{|c|c|c|c|}
\hline Author name & Journal name & Year, volume, page\# & Note \\
\hline Ball \& Ryden & Biological processes and soil fertility & $1984,23-33$ & Book \\
\hline Barraclough et al. & Soil Use and Management & $1992,8(2), 51-55$ & \\
\hline Chapin III et al. & The American Naturalist & $1986,127(1), 48-58$ & \\
\hline Di \& Cameron & New Zealand Journal ofAgricultural Research & $2004,47(3), 351-361$ & \\
\hline Erisman et al. & Environmental pollution & $2007,150(1), 140-149$ & \\
\hline Field et al. & $\begin{array}{l}\text { Proceedings of the New Zealand Grassland } \\
\text { Association }\end{array}$ & $1985,209-214$ & Conference \\
\hline Gong et al. & Plant and Soil & $2011,340(1-2), 227-238$ & \\
\hline Gourley et al. & Animal Production Science & $2012,52(10), 929-944$ & \\
\hline Hobbs et al. & Ecology & $1991,72(4), 1374-1382$ & \\
\hline $\begin{array}{l}\text { Høgh-Jensen \& } \\
\text { Schjørring }\end{array}$ & Plant and Soil & 1997, 197 (2), 187-199 & \\
\hline Janssen & $\begin{array}{l}\text { Nutrient disequilibria in agroecosystems: Concepts } \\
\text { and case studies }\end{array}$ & $1999,27-56$ & Book \\
\hline Knapp \& Seastedt & BioScience & $1986,36(10), 662-668$ & \\
\hline Lambert et al. & New Zealand Journal ofAgricultural Research & $1985,28(3), 371-379$ & \\
\hline Ledgard et al. & The Journal of Agricultural Science & $1999,132(2), 215-225$ & \\
\hline Ledgard & Plant and Soil & $2001,228(1), 43-59$ & \\
\hline Lü et al. & Plant and Soil & $2015,387(1-2), 69-79$ & \\
\hline Monaghan et al. & New Zealand Journal ofAgricultural Research & $2007,50(2), 181-201$ & \\
\hline Ojima et al. & Biogeochemistry & $1994,24(2), 67-84$ & \\
\hline Peoples et al. & Australian Journal of Agricultural Research & $1998,49(3), 459-474$ & \\
\hline Phillips et al. & New Phytologist & $2013,199(1), 41-51$ & \\
\hline Phillips et al. & Ecology letters & $2011,14(2), 187-194$ & \\
\hline Powell et al. & Environmental Science \& Policy & $2010,13(3), 217-228$ & \\
\hline Roten et al. & Computers and Electronics inAgriculture & 2017,135 128-133 & \\
\hline Rufino et al. & Agriculture, Ecosystems \& Environment & $2006,112(4), 261-282$ & \\
\hline Scholefield et al. & Journal of Soil Science & $1993,44(4), 601-613$ & \\
\hline Schröder et al. & European Journal of Agronomy & $2003,20(1-2), 33-44$ & \\
\hline Seastedt \& Ramundo & Fire in North American tallgrass prairies. & $1990,99-117$ & Book \\
\hline Smith & Ecology & $1976,57(2), 324-331$ & \\
\hline Tilman \& Wedin & Ecology & $1991,72(2), 685-700$ & \\
\hline Trotter et al. & Crop and Pasture Science & $2014,65(8), 817-827$ & \\
\hline Van der Hoek & Nitrogen, the confer-ns & $1998,127-132$ & Book \\
\hline Van Noordwijk & $\begin{array}{l}\text { Nutrient cycles and nutrient budgets in global } \\
\text { agro-ecosystems. }\end{array}$ & $1999,1-26$ & Book \\
\hline $\begin{array}{l}\text { VandeHaar \& } \\
\text { St-Pierre }\end{array}$ & Journal of dairy science & $2006,89(4), 1280-1291$ & \\
\hline Vitousek & The American Naturalist & $1982,119(4), 553-572$ & \\
\hline Wedin \& Tilman & Oecologia & $1990,84(4), 433-441$ & \\
\hline
\end{tabular}


Table A3. Cont.

\begin{tabular}{|c|c|c|c|}
\hline Author name & Journal name & Year, volume, page\# & Note \\
\hline Wilkins et al. & Grass and Forage Science & $2000,55(1), 69-76$ & \\
\hline Wilkins et al. & Euphytica & $1997,98(1-2), 109-119$ & \\
\hline Yin et al. & Soil Biology and Biochemistry & 2014,78 213-221 & \\
\hline
\end{tabular}

Notes: Books are marked as "Book" and conference papers are marked as "Conference" in the "Note" column.

Table A4. Papers selected associated with the effects of grazing land managements on other ecosystem functions.

\begin{tabular}{|c|c|c|c|}
\hline Author name & Journal name & Year, volume, page\# & Note \\
\hline Al-Kaisi \& Lowery & Soil health and intensification of agroecosystems & 2017 & Book \\
\hline Ayres et al. & Functional Ecology & $2007,21(2), 256-263$ & \\
\hline Bagchi \& Ritchie & Ecology letters & $2010,13(8), 959-968$ & \\
\hline Bardgett \& Wardle & $\begin{array}{l}\text { Aboveground-belowground linkages: Biotic interactions, } \\
\text { ecosystem processes, and global change }\end{array}$ & 2010 & Book \\
\hline Flack & $\begin{array}{l}\text { The art and science of grazing: How grass farmers can } \\
\text { create sustainable systems for healthy animals and farm } \\
\text { ecosystems }\end{array}$ & $2017,7-10$ & Book \\
\hline Belnap & Frontiers in Ecology and the Environment & $2003,1(4), 181-189$ & \\
\hline Bond \& Keeley & Trends in ecology \& evolution & $2005,20(7), 387-394$ & \\
\hline Buckley et al. & Nutrient cycling in agroecosystems & 2016, $104(1), 1-13$ & \\
\hline Cherif \& Loreau & Proc. R. Soc. B & 2013, 280 (1754), 20122453 & \\
\hline Frank \& Groffman & Ecology & 1998,79 (7), 2229-2241 & \\
\hline Frink et al. & Proceedings of the National Academy of Sciences & $1999,96(4), 1175-1180$ & \\
\hline Fuhlendorf et al. & Applied Vegetation Science & $2001,4(2), 177-188$ & \\
\hline Gao et al. & Research Journal of Agriculture and BiologicalSciences & $2007,3(6), 642-647$ & \\
\hline Hamilton III \& Frank & Ecology & $2001,82(9), 2397-2402$ & \\
\hline Han et al. & Agriculture, Ecosystems \& Environment & $2008,125(1-4), 21-32$ & \\
\hline Hart & Plant Ecology & $2001,155(1), 111-118$ & \\
\hline Hobbs & The Journal of Wildlife Management & $1996,695-713$ & \\
\hline Kersebaum et al. & Physics and Chemistry of the Earth, Parts A/B/C & 2003, $28(12-13), 537-545$ & \\
\hline Keya & Agriculture, Ecosystems \& Environment & $1998,69(1), 55-67$ & \\
\hline Knicker & Biogeochemistry & 2007,85 (1), 91-118 & \\
\hline Leriche et al. & Oecologia & 2001,129 (1), 114-124 & \\
\hline Manzano \& Návar & Journal of Arid Environments & $2000,44(1), 1-17$ & \\
\hline McDowell. & Environmental impacts of pasture-based farming & $2008,33-76$ & Book \\
\hline Morris \& Jensen & Journal of Ecology & $1998,86(2), 229-242$ & \\
\hline Mueller et al. & Ecological Applications & $2017,27(5), 1435-1450$ & \\
\hline Neff et al. & Ecological Applications & $2005,15(1), 87-95$ & \\
\hline Ning et al. & Rangifer & $2004,24(4), 9-15$ & \\
\hline Nolte et al. & Estuarine, Coastal and Shelf Science & $2013,135296-305$ & \\
\hline Oenema et al. & Nitrogen, the confer-ns & $1998,471-478$ & Book \\
\hline Oesterheld et al. & Ecosystems of the world & $1999,287-306$ & \\
\hline Olsen et al. & Soil Biology and Biochemistry & $2011,43(3), 531-541$ & \\
\hline Pandey \& Singh & Canadian Journal of Botany & 1992, 70 (9), 18851890 & \\
\hline Peoples et al. & Plant and Soil & $1995,174(1-2), 3-28$ & \\
\hline Piñeiro et al. & Rangeland Ecology \& Management & 2010, $63(1), 109-119$ & \\
\hline Renzhong \& Ripley & Journal of Arid Environments & $1997,36(2), 307-318$ & \\
\hline Rosser \& Ross & New Zealand Journal of Agricultural Research & $2011,54(1), 23-44$ & \\
\hline Seagle et al. & Ecology & $1992,73(3), 1105-1123$ & \\
\hline Smith et al. & New Zealand Journal of Agricultural Research & $2012,55(2), 105-117$ & \\
\hline Sun et al. & Plant and Soil & $2017,416(1-2), 515-525$ & \\
\hline Thomas & Grass and Forage Science & $1992,47(2), 133-142$ & \\
\hline Vallentine & Grazing management & 2000 & Book \\
\hline Virgona et al. & Australian Journal of Agricultural Research & 2006,57 (12), 1307-1319 & \\
\hline Wang et al. & Catena & 2017,158 141-147 & \\
\hline Waters et al. & The Rangeland Journal & 2015,37 (3), 297-307 & \\
\hline Wilson et al. & Journal of Soil and Water Conservation & $2014,69(4), 330-342$ & \\
\hline Xu et al. & Geoderma & $2017,29373-81$ & \\
\hline Zhu et al. & Journal of Arid Environments & $2015,11441-48$ & \\
\hline
\end{tabular}




\section{Appendix B}

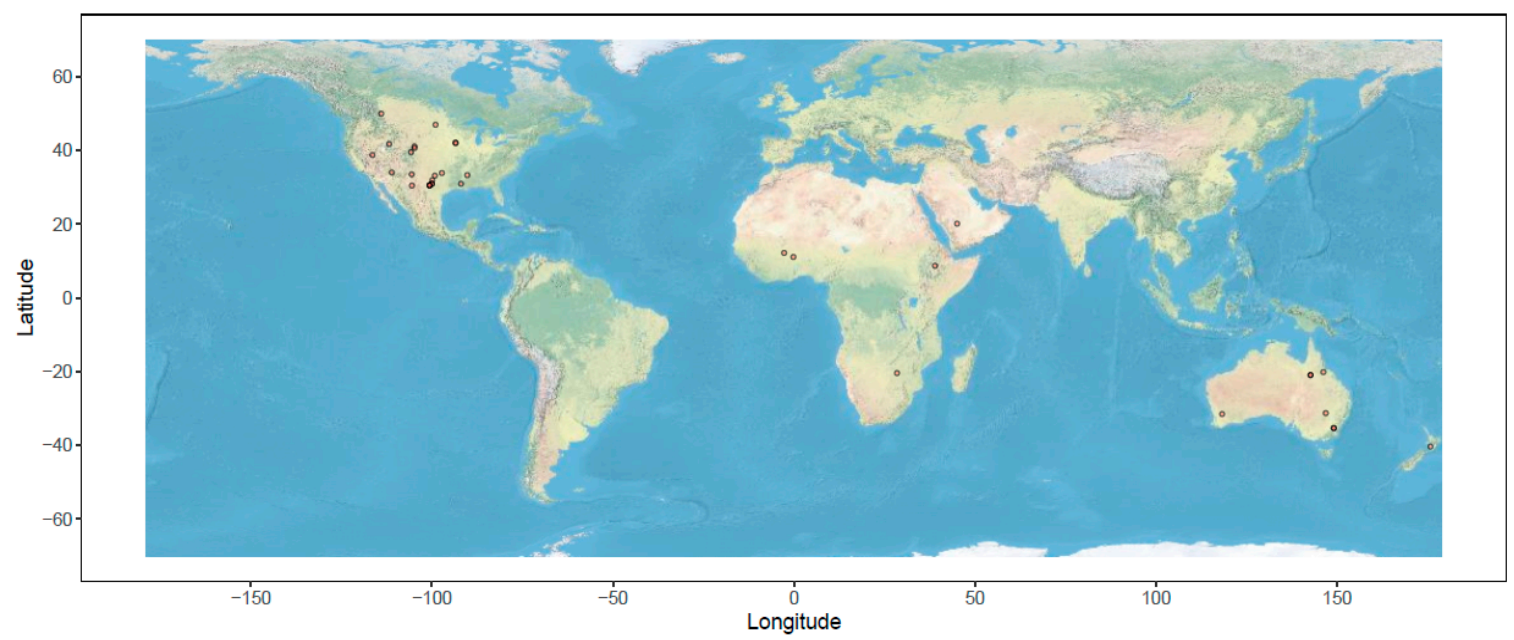

Figure A1. Locations of reviewed articles related to the effect of grazing land management on water infiltration.

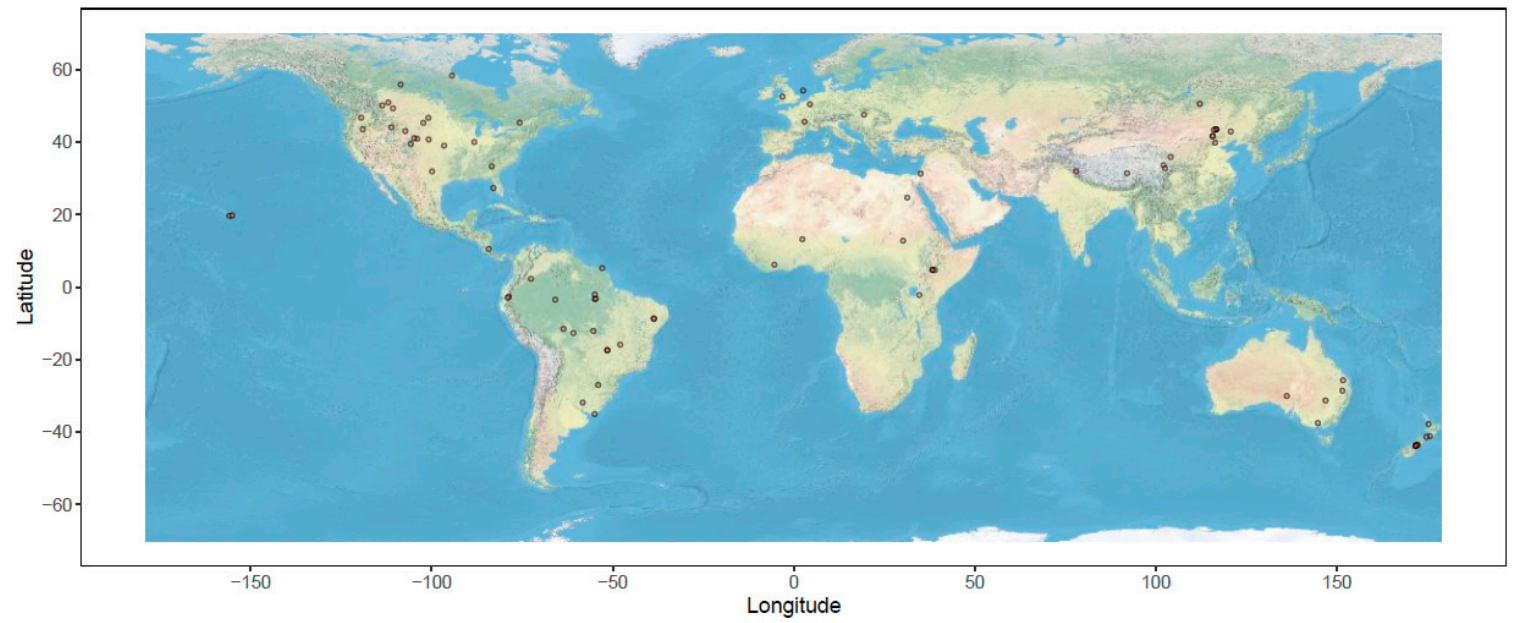

Figure A2. Locations of reviewed articles related to the effect of grazing land management on soil carbon sequestration.

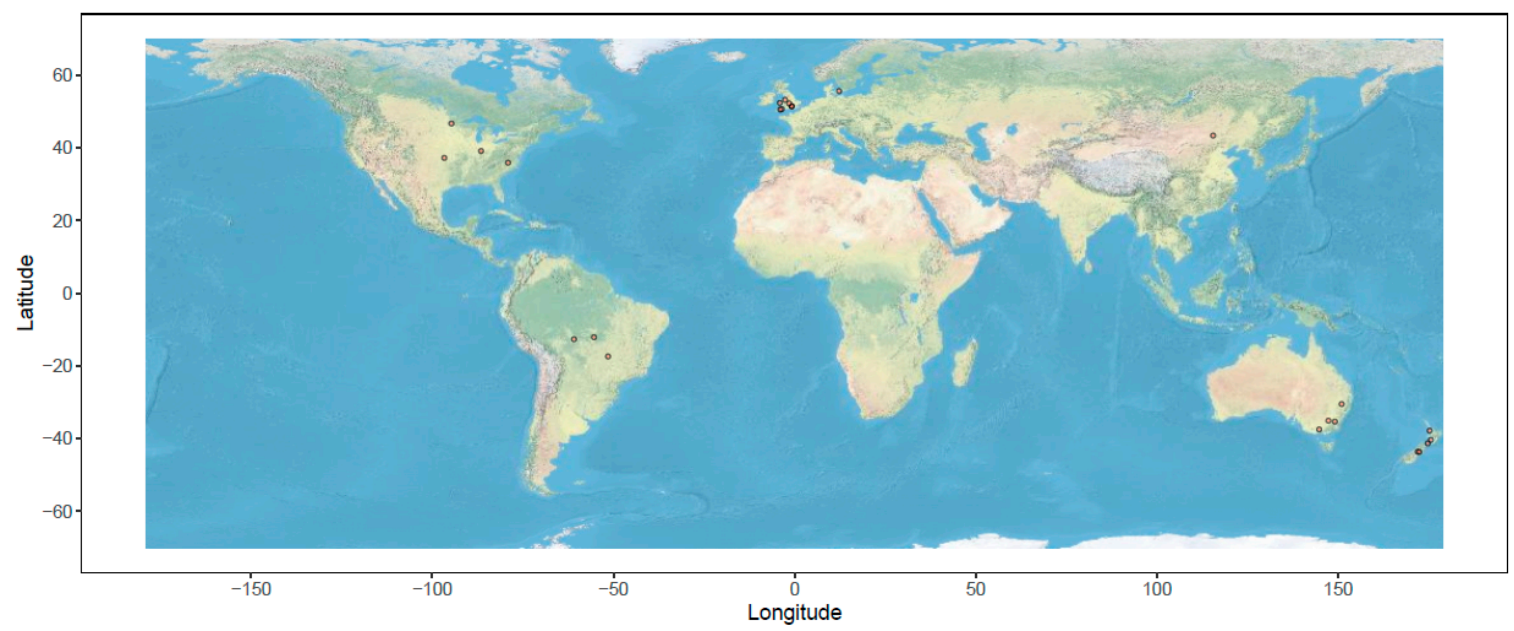

Figure A3. Locations of reviewed articles related to the effect of grazing land management on nitrogen use efficiency. 


\section{References}

1. Follett, R.F.; Reed, D.A. Soil carbon sequestration in grazing lands: Societal benefits and policy implications. Rangel. Ecol. Manag. 2010, 63, 4-15. [CrossRef]

2. Conant, R.T.; Paustian, K.; Elliott, E.T. Grassland management and conversion into grassland: Effects on soil carbon. Ecol. Appl. 2001, 11, 343-355. [CrossRef]

3. Conant, R.T.; Cerri, C.E.; Osborne, B.B.; Paustian, K. Grassland management impacts on soil carbon stocks: A new synthesis. Ecol. Appl. 2017, 27, 662-668. [CrossRef] [PubMed]

4. Wang, T.; Zhang, Z.; Li, Z.; Li, P. Grazing management affects plant diversity and soil properties in a temperate steppe in northern China. Catena 2017, 158, 141-147. [CrossRef]

5. Flack, S. The Art and Science of Grazing: How Grass Farmers Can Create Sustainable Systems for Healthy Animals and Farm Ecosystems; Chelsea Green Publishing: White River Junction, VT, USA, 2016; pp. 7-10. ISBN 9781603586122.

6. McDowell, R.W. Environmental Impacts of Pasture-Based Farming; Cabi: Oxfordshire, UK, 2008; pp. 33-76. ISBN 978-1-84593-411-8.

7. Wall, D.H.; Bardgett, R.D. Soil Ecology and Ecosystem Services; Oxford University Press: Oxford, UK, 2012; pp. 282-295. ISBN 978-0-19-957592-3.

8. Weil, R.R.; Brady, N.C. The Nature and Properties of Soils, 15th ed.; Pearson: London, UK, 2017; pp. $745-873$. ISBN 0133254488.

9. USDA Soil Health. Available online: https://www.nrcs.usda.gov/wps/portal/nrcs/main/soils/health/ (accessed on 6 August 2018).

10. Abdel-Magid, A.H.; Schuman, G.E.; Hart, R.H. Soil bulk density and water infiltration as affected by grazing systems. J. Range Manag. 1987, 40, 307-309. [CrossRef]

11. Yisehak, K.; Belay, D.; Taye, T.; Janssens, G.P. Impact of soil erosion associated factors on available feed resources for free-ranging cattle at three altitude regions: Measurements and perceptions. J. Arid Environ. 2013, 98, 70-78. [CrossRef]

12. Vandandorj, S.; Eldridge, D.J.; Travers, S.K.; Val, J.; Oliver, I. Microsite and grazing intensity drive infiltration in a semiarid woodland. Ecohydrology 2017, 10, e1831. [CrossRef]

13. Lal, R. Carbon sequestration in dryland ecosystems. Environ. Manag. 2004, 33, 528-544. [CrossRef]

14. Prăvălie, R. Drylands extent and environmental issues. A global approach. Earth-Sci. Rev. 2016, 161, $259-278$. [CrossRef]

15. Magdoff, F.; Weil, R.R. Significance of Soil Organic Matter to Soil Quality and Health. In Soil Organic Matter in Sustainable Agriculture; Magdoff, F., Weil, R.R., Eds.; CRC Press: Boca Raton, FL, USA, 2004; pp. 1-43. ISBN 978-0-203-49637-4.

16. Chen, W.; Huang, D.; Liu, N.; Zhang, Y.; Badgery, W.B.; Wang, X.; Shen, Y. Improved grazing management may increase soil carbon sequestration in temperate steppe. Sci. Rep. 2015, 5, 10892. [CrossRef]

17. Burke, I.C.; Lauenroth, W.K.; Milchunas, D.G. Biogeochemistry of Managed Grasslands in Central North America. In Soil Organic Matter in Temperate AgroecosystemsLong Term Experiments in North America; Paul, E.A., Paustian, K.H., Elliott, E.T., Cole, C.V., Eds.; CRC Press: Boca Raton, FL, USA, 1996; pp. 85-98. ISBN 0-8493-2802-0.

18. Lü, X.-T.; Freschet, G.T.; Kazakou, E.; Wang, Z.-W.; Zhou, L.-S.; Han, X.-G. Contrasting responses in leaf nutrient-use strategies of two dominant grass species along a 30-yr temperate steppe grazing exclusion chronosequence. Plant Soil 2015, 387, 69-79. [CrossRef]

19. Trotter, M.; Guppy, C.; Haling, R.; Trotter, T.; Edwards, C.; Lamb, D. Spatial variability in pH and key soil nutrients: Is this an opportunity to increase fertiliser and lime-use efficiency in grazing systems? Crop Pasture Sci. 2014, 65, 817-827. [CrossRef]

20. Virgona, J.; Gummer, F.; Angus, J. Effects of grazing on wheat growth, yield, development, water use, and nitrogen use. Aust. J. Agric. Res. 2006, 57, 1307-1319. [CrossRef]

21. GR McCalla, I.; Blackburn, W.; Merrill, L. Effects of livestock grazing on infiltration rates, Edwards Plateau of Texas. J. Range Manag. 1984, 37, 265-269. [CrossRef]

22. Teague, W.; Dowhower, S.; Baker, S.; Haile, N.; DeLaune, P.; Conover, D. Grazing management impacts on vegetation, soil biota and soil chemical, physical and hydrological properties in tall grass prairie. Agric. Ecosyst. Environ. 2011, 141, 310-322. [CrossRef] 
23. Dadkhah, M.; Gifford, G.F. Influence of vegetation, rock cover, and trampling on infiltration rates and sediment production. J. Am. Water Resour. Assoc. 1980, 16, 979-986. [CrossRef]

24. Proffitt, A.; Bendotti, S.; Howell, M.; Eastham, J. The effect of sheep trampling and grazing on soil physical properties and pasture growth for a red-brown earth. Aust. J. Agric. Res. 1993, 44, 317-331. [CrossRef]

25. Savadogo, P.; Sawadogo, L.; Tiveau, D. Effects of grazing intensity and prescribed fire on soil physical and hydrological properties and pasture yield in the savanna woodlands of Burkina Faso. Agric. Ecosyst. Environ. 2007, 118, 80-92. [CrossRef]

26. Eldridge, D.J.; Poore, A.G.; Ruiz-Colmenero, M.; Letnic, M.; Soliveres, S. Ecosystem structure, function, and composition in rangelands are negatively affected by livestock grazing. Ecol. Appl. 2016, 26, 1273-1283. [CrossRef]

27. McGinty, W.A.; Smeins, F.E.; Merrill, L.B. Influence of soil, vegetation, and grazing management on infiltration rate and sediment production of Edwards Plateau rangeland. J. Range Manag. 1979, 32, 33-37. [CrossRef]

28. Gamougoun, N.D.; Smith, R.P.; Wood, M.K.; Pieper, R.D. Soil, vegetation, and hydrologic responses to grazing management at Fort Stanton, New Mexico. J. Range Manag. 1984, 538-541. [CrossRef]

29. Castellano, M.; Valone, T. Livestock, soil compaction and water infiltration rate: Evaluating a potential desertification recovery mechanism. J. Arid Environ. 2007, 71, 97-108. [CrossRef]

30. Fraser, G.; Stone, G. The effect of soil and pasture attributes on rangeland infiltration rates in northern Australia. Rangel. J. 2016, 38, 245-259. [CrossRef]

31. Talore, D.G.; Tesfamariam, E.H.; Hassen, A.; Du Toit, J.; Klampp, K.; Jean-Francois, S. Long-term impacts of grazing intensity on soil carbon sequestration and selected soil properties in the arid Eastern Cape, South Africa. J. Sci. Food Agric. 2016, 96, 1945-1952. [CrossRef]

32. Rauzi, F.; Smith, F.M. Infiltration rates: Three soils with three grazing levels in northeastern Colorado. J. Range Manag. 1973, 126-129. [CrossRef]

33. Warren, S.; Blackburn, W.; Taylor, C., Jr. Soil hydrologic response to number of pastures and stocking density under intensive rotation grazing. J. Range Manag. 1986, 500-504. [CrossRef]

34. Mwendera, E.; Saleem, M. Infiltration rates, surface runoff, and soil loss as influenced by grazing pressure in the Ethiopian highlands. Soil Use Manag. 1997, 13, 29-35. [CrossRef]

35. Daniel, J.; Potter, K.; Altom, W.; Aljoe, H.; Stevens, R. Long-term grazing density impacts on soil compaction. Trans. ASAE 2002, 45, 1911. [CrossRef]

36. Thurow, T.L.; Blackburn, W.H.; Taylor, C.A., Jr. Infiltration and interrill erosion responses to selected livestock grazing strategies, Edwards Plateau, Texas. J. Range Manag. 1988, 296-302. [CrossRef]

37. Pluhar, J.; Knight, R.; Heitschmidt, R. Infiltration rates and sediment production as influenced by grazing systems in the Texas Rolling Plains. J. Range Manag. 1987, 240-243. [CrossRef]

38. Wood, M.K.; Blackburn, W.H. Grazing systems: Their influence on infiltration rates in the Rolling Plains of Texas. J. Range Manag. 1981, 331-335. [CrossRef]

39. Thurow, T.; Blackburn, W.; Taylor, C., Jr. Hydrologic characteristics of vegetation types as affected by livestock grazing systems, Edwards Plateau, Texas. J. Range Manag. 1986, 505-509. [CrossRef]

40. Sharrow, S.H. Soil compaction by grazing livestock in silvopastures as evidenced by changes in soil physical properties. Agrofor. Syst. 2007, 71, 215-223. [CrossRef]

41. Fuhlendorf, S.D.; Briske, D.D.; Smeins, F.E. Herbaceous vegetation change in variable rangeland environments: The relative contribution of grazing and climatic variability. Appl. Veg. Sci. 2001, 4, 177-188. [CrossRef]

42. Keya, G.A. Herbaceous layer production and utilization by herbivores under different ecological conditions in an arid savanna of Kenya. Agric. Ecosyst. Environ. 1998, 69, 55-67. [CrossRef]

43. Rietkerk, M.; Ketner, P.; Burger, J.; Hoorens, B.; Olff, H. Multiscale soil and vegetation patchiness along a gradient of herbivore impact in a semi-arid grazing system in West Africa. Plant Ecol. 2000, 148, 207-224. [CrossRef]

44. Gilley, J.E.; Patton, B.; Nyren, P.; Simanton, J. Grazing and haying effects on runoff and erosion from a former conservation reserve program site. Appl. Eng. Agric. 1996, 12, 681-684. [CrossRef]

45. Sanjari, G.; Yu, B.; Ghadiri, H.; Ciesiolka, C.A.; Rose, C.W. Effects of time-controlled grazing on runoff and sediment loss. Soil Res. 2010, 47, 796-808. [CrossRef] 
46. Park, J.; Ale, S.; Teague, W.; Dowhower, S. Simulating hydrologic responses to alternate grazing management practices at the ranch and watershed scales. J. Soil Water Conserv. 2017, 72, 102-121. [CrossRef]

47. Wilson, G.L.; Dalzell, B.J.; Mulla, D.J.; Dogwiler, T.; Porter, P.M. Estimating water quality effects of conservation practices and grazing land use scenarios. J. Soil Water Conserv. 2014, 69, 330-342. [CrossRef]

48. Takar, A.; Dobrowolski, J.; Thurow, T. Influence of grazing, vegetation life-form, and soil type on infiltration rates and interrill erosion on a Somalion rangeland. J. Range Manag. 1990, 486-490. [CrossRef]

49. McIvor, J.G.; Williams, J.; Gardener, C.J. Pasture management influences runoff and soil movement in the semi-arid tropics. Aust. J. Exp. Agric. 1995, 35, 55-65. [CrossRef]

50. Kirschbaum, M.U.; Schipper, L.A.; Mudge, P.L.; Rutledge, S.; Puche, N.J.; Campbell, D.I. The trade-offs between milk production and soil organic carbon storage in dairy systems under different management and environmental factors. Sci. Total Environ. 2017, 577, 61-72. [CrossRef] [PubMed]

51. Frank, A.; Tanaka, D.; Hofmann, L.; Follett, R. Soil carbon and nitrogen of Northern Great Plains grasslands as influenced by long-term grazing. J. Range Manag. 1995, 470-474. [CrossRef]

52. Schuman, G.; Reeder, J.; Manley, J.; Hart, R.; Manley, W. Impact of grazing management on the carbon and nitrogen balance of a mixed-grass rangeland. Ecol. Appl. 1999, 9, 65-71. [CrossRef]

53. Manzano, M.G.; Návar, J. Processes of desertification by goats overgrazing in the Tamaulipan thornscrub (matorral) in north-eastern Mexico. J. Arid Environ. 2000, 44, 1-17. [CrossRef]

54. Reeder, J.; Schuman, G. Influence of livestock grazing on C sequestration in semi-arid mixed-grass and short-grass rangelands. Environ. Pollut. 2002, 116, 457-463. [CrossRef]

55. Oesterheld, M.; Loreti, J.; Semmartin, M.; Paruelo, J. Grazing, fire, and climate effects on primary productivity of grasslands and savannas. In Ecosystems of Disturbed Ground; Walker, L.R., Ed.; Ecosystems of the World; Elsevier: New York, NY, USA, 1999; pp. 287-306. ISBN 0444824200.

56. Piñeiro, G.; Paruelo, J.M.; Oesterheld, M.; Jobbágy, E.G. Pathways of grazing effects on soil organic carbon and nitrogen. Rangel. Ecol. Manag. 2010, 63, 109-119. [CrossRef]

57. Zhu, L.; Johnson, D.A.; Wang, W.; Ma, L.; Rong, Y. Grazing effects on carbon fluxes in a Northern China grassland. J. Arid Environ. 2015, 114, 41-48. [CrossRef]

58. Naeth, M.; Bailey, A.; Pluth, D.; Chanasyk, D.; Hardin, R. Grazing impacts on litter and soil organic matter in mixed prairie and fescue grassland ecosystems of Alberta. J. Range Manag. 1991, 7-12. [CrossRef]

59. Shariff, A.R.; Biondini, M.E.; Grygiel, C.E. Grazing intensity effects on litter decomposition and soil nitrogen mineralization. J. Range Manag. 1994, 444-449. [CrossRef]

60. Schipper, L.A.; Mudge, P.L.; Kirschbaum, M.U.; Hedley, C.B.; Golubiewski, N.E.; Smaill, S.J.; Kelliher, F.M. A review of soil carbon change in New Zealand's grazed grasslands. N. Z. J. Agric. Res. 2017, 60, 93-118. [CrossRef]

61. Schuman, G.; Janzen, H.; Herrick, J. Soil carbon dynamics and potential carbon sequestration by rangelands. Environ. Pollut. 2002, 116, 391-396. [CrossRef]

62. Dormaar, J.; Johnston, A.; Smoliak, S. Seasonal variation in chemical characteristics of soil organic matter of grazed and ungrazed mixed prairie and fescue grassland. J. Range Manag. 1977, 195-198. [CrossRef]

63. Reeder, J.D.; Schuman, G.E.; Morgan, J.A.; LeCain, D.R. Response of organic and inorganic carbon and nitrogen to long-term grazing of the shortgrass steppe. Environ. Manag. 2004, 33, 485-495. [CrossRef]

64. Su, Y.-Z.; Li, Y.-L.; Cui, J.-Y.; Zhao, W.-Z. Influences of continuous grazing and livestock exclusion on soil properties in a degraded sandy grassland, Inner Mongolia, northern China. Catena 2005, 59, 267-278. [CrossRef]

65. Li, X.; Fu, H.; Li, X.; Guo, D.; Dong, X.; Wan, C. Effects of land-use regimes on carbon sequestration in the Loess Plateau, northern China. N. Z. J. Agric. Res. 2008, 51, 45-52. [CrossRef]

66. Shrestha, G.; Stahl, P.D. Carbon accumulation and storage in semi-arid sagebrush steppe: Effects of long-term grazing exclusion. Agric. Ecosyst. Environ. 2008, 125, 173-181. [CrossRef]

67. Witt, G.B.; Noël, M.V.; Bird, M.I.; Beeton, R.B.; Menzies, N.W. Carbon sequestration and biodiversity restoration potential of semi-arid mulga lands of Australia interpreted from long-term grazing exclosures. Agric. Ecosyst. Environ. 2011, 141, 108-118. [CrossRef]

68. Xiong, D.; Shi, P.; Sun, Y.; Wu, J.; Zhang, X. Effects of grazing exclusion on plant productivity and soil carbon, nitrogen storage in alpine meadows in northern Tibet, China. Chin. Geogr. Sci. 2014, 24, 488-498. [CrossRef]

69. Ma, W.; Ding, K.; Li, Z. Comparison of soil carbon and nitrogen stocks at grazing-excluded and yak grazed alpine meadow sites in Qinghai-Tibetan Plateau, China. Ecol. Eng. 2016, 87, 203-211. [CrossRef] 
70. Orgill, S.E.; Condon, J.R.; Conyers, M.K.; Morris, S.G.; Alcock, D.J.; Murphy, B.W.; Greene, R.S.B. Removing grazing pressure from a native pasture decreases soil organic carbon in southern New South Wales, Australia. Land Degrad. Dev. 2018, 29, 274-283. [CrossRef]

71. Aynekulu, E.; Mekuria, W.; Tsegaye, D.; Feyissa, K.; Angassa, A.; de Leeuw, J.; Shepherd, K. Long-term livestock exclosure did not affect soil carbon in southern Ethiopian rangelands. Geoderma 2017, 307, 1-7. [CrossRef]

72. Feyisa, K.; Beyene, S.; Angassa, A.; Said, M.Y.; de Leeuw, J.; Abebe, A.; Megersa, B. Effects of enclosure management on carbon sequestration, soil properties and vegetation attributes in East African rangelands. Catena 2017, 159, 9-19. [CrossRef]

73. Gao, Y.; Luo, P.; Wu, N.; Chen, H.; Wang, G. Grazing intensity impacts on carbon sequestration in an alpine meadow on the eastern Tibetan Plateau. Res. J. Agric. Biol. Sci. 2007, 3, 642-647.

74. Ingram, L.; Stahl, P.; Schuman, G.; Buyer, J.; Vance, G.; Ganjegunte, G.; Welker, J.; Derner, J. Grazing impacts on soil carbon and microbial communities in a mixed-grass ecosystem. Soil Sci. Soc. Am. J. 2008, 72, 939-948. [CrossRef]

75. Liu, N.; Zhang, Y.; Chang, S.; Kan, H.; Lin, L. Impact of grazing on soil carbon and microbial biomass in typical steppe and desert steppe of Inner Mongolia. PLoS ONE 2012, 7, e36434. [CrossRef]

76. Conant, R.T.; Paustian, K. Potential soil carbon sequestration in overgrazed grassland ecosystems. Glob. Biogeochem. Cycles 2002, 16, 90-1-90-9. [CrossRef]

77. Liebig, M.; Gross, J.; Kronberg, S.; Hanson, J.; Frank, A.; Phillips, R. Soil response to long-term grazing in the northern Great Plains of North America. Agric. Ecosyst. Environ. 2006, 115, 270-276. [CrossRef]

78. Mortenson, M.C.; Schuman, G.E.; Ingram, L.J. Carbon sequestration in rangelands interseeded with yellow-flowering alfalfa (Medicago sativa ssp. falcata). Environ. Manag. 2004, 33, S475-S481. [CrossRef]

79. Carvalho, J.L.N.; Raucci, G.S.; Frazão, L.A.; Cerri, C.E.P.; Bernoux, M.; Cerri, C.C. Crop-pasture rotation: A strategy to reduce soil greenhouse gas emissions in the Brazilian Cerrado. Agric. Ecosyst. Environ. 2014, 183, 167-175. [CrossRef]

80. Bagchi, S.; Roy, S.; Maitra, A.; Sran, R.S. Herbivores suppress soil microbes to influence carbon sequestration in the grazing ecosystem of the Trans-Himalaya. Agric. Ecosyst. Environ. 2017, 239, 199-206. [CrossRef]

81. Nolte, S.; Müller, F.; Schuerch, M.; Wanner, A.; Esselink, P.; Bakker, J.P.; Jensen, K. Does livestock grazing affect sediment deposition and accretion rates in salt marshes? Estuar. Coast. Shelf Sci. 2013, 135, 296-305. [CrossRef]

82. Xiong, D.; Shi, P.; Zhang, X.; Zou, C.B. Effects of grazing exclusion on carbon sequestration and plant diversity in grasslands of China-A meta-analysis. Ecol. Eng. 2016, 94, 647-655. [CrossRef]

83. Reeder, J.; Franks, C.; Milchunas, D.; Follett, R.; Kimble, J. Root biomass and microbial processes. In The Potential of US Grazing Lands to Sequester Carbon and Mitigate the Greenhouse Effect; Kimble, J.M., Follett, R.F., Eds.; CRC Press: Boca Raton, FL, USA; Lewis Publishers: Boca Raton, FL, USA, 2001; pp. $139-166$. ISBN 9781420032468.

84. Milchunas, D.; Lauenroth, W.; Chapman, P. Plant competition, abiotic, and long-and short-term effects of large herbivores on demography of opportunistic species in a semiarid grassland. Oecologia 1992, 92, 520-531. [CrossRef] [PubMed]

85. Frank, D.A.; McNaughton, S.J. Evidence for the promotion of aboveground grassland production by native large herbivores in Yellowstone National Park. Oecologia 1993, 96, 157-161. [CrossRef] [PubMed]

86. Briske, D.D.; Richards, J.H. Plant responses to defoliation: A physiological, morphological and demographic evaluation. In Wildland Plants: Physiological Ecology and Developmental Morphology; Bedunah, J., Sosebee, R.E., Eds.; Society for Range Management: Littleton, CO, USA, 1995; pp. 635-710. ISBN 1884930026.

87. Doescher, P.; Svejcar, T.; Jaindl, R. Gas exchange of Idaho fescue in response to defoliation and grazing history. J. Range Manag. 1997, 285-289. [CrossRef]

88. Frank, D.A.; Kuns, M.M.; Guido, D.R. Consumer control of grassland plant production. Ecology 2002, 83, 602-606. [CrossRef]

89. Bagchi, S.; Ritchie, M.E. Introduced grazers can restrict potential soil carbon sequestration through impacts on plant community composition. Ecol. Lett. 2010, 13, 959-968. [CrossRef]

90. Olsen, Y.S.; Dausse, A.; Garbutt, A.; Ford, H.; Thomas, D.N.; Jones, D.L. Cattle grazing drives nitrogen and carbon cycling in a temperate salt marsh. Soil Biol. Biochem. 2011, 43, 531-541. [CrossRef] 
91. McNaughton, S. Grazing as an optimization process: Grass-ungulate relationships in the Serengeti. Am. Nat. 1979, 113, 691-703. [CrossRef]

92. Hik, D.; Jefferies, R. Increases in the net above-ground primary production of a salt-marsh forage grass: A test of the predictions of the herbivore-optimization model. J. Ecol. 1990, 180-195. [CrossRef]

93. Hart, R.H. Plant biodiversity on shortgrass steppe after 55 years of zero, light, moderate, or heavy cattle grazing. Plant Ecol. 2001, 155, 111-118. [CrossRef]

94. Rong, Y.; Johnson, D.A.; Wang, Z.; Zhu, L. Grazing effects on ecosystem CO2 fluxes regulated by interannual climate fluctuation in a temperate grassland steppe in northern China. Agric. Ecosyst. Environ. 2017, 237, 194-202. [CrossRef]

95. Neff, J.; Reynolds, R.; Belnap, J.; Lamothe, P. Multi-decadal impacts of grazing on soil physical and biogeochemical properties in southeast Utah. Ecol. Appl. 2005, 15, 87-95. [CrossRef]

96. He, N.; Zhang, Y.; Yu, Q.; Chen, Q.; Pan, Q.; Zhang, G.; Han, X. Grazing intensity impacts soil carbon and nitrogen storage of continental steppe. Ecosphere 2011, 2, 1-10. [CrossRef]

97. Li, W.; Huang, H.-Z.; Zhang, Z.-N.; Wu, G.-L. Effects of grazing on the soil properties and C and N storage in relation to biomass allocation in an alpine meadow. J. Soil Sci. Plant Nutr. 2011, 11, 27-39. [CrossRef]

98. Sanjari, G.; Ghadiri, H.; Ciesiolka, C.A.; Yu, B. Comparing the effects of continuous and time-controlled grazing systems on soil characteristics in Southeast Queensland. Soil Res. 2008, 46, 348-358. [CrossRef]

99. Sanderman, J.; Reseigh, J.; Wurst, M.; Young, M.-A.; Austin, J. Impacts of rotational grazing on soil carbon in native grass-based pastures in southern Australia. PLoS ONE 2015, 10, e0136157. [CrossRef]

100. Alemu, A.; Iwaasa, A.; Kröbel, R.; McConkey, B. 294 Productivity and carbon sequestration potential of reestablished native grassland in Canadian prairie following grazing. J. Anim. Sci. 2017, 95 (Suppl. 4), 145-146. [CrossRef]

101. Teixeira, R.; Domingos, T.; Costa, A.; Oliveira, R.; Farropas, L.; Calouro, F.; Barradas, A.; Carneiro, J. Soil organic matter dynamics in Portuguese natural and sown rainfed grasslands. Ecol. Model. 2011, 222, 993-1001. [CrossRef]

102. Teixeira, R.F.; Proença, V.; Crespo, D.; Valada, T.; Domingos, T. A conceptual framework for the analysis of engineered biodiverse pastures. Ecol. Eng. 2015, 77, 85-97. [CrossRef]

103. Aires, L.M.I.; Pio, C.A.; Pereira, J.S. Carbon dioxide exchange above a Mediterranean C3/C4 grassland during two climatologically contrasting years. Glob. Chang. Biol. 2008, 14, 539-555. [CrossRef]

104. Guo, L.B.; Gifford, R. Soil carbon stocks and land use change: A meta analysis. Glob. Chang. Biol. 2002, 8, 345-360. [CrossRef]

105. Powers, J.S.; Veldkamp, E. Regional variation in soil carbon and $\delta 13 \mathrm{C}$ in forests and pastures of northeastern Costa Rica. Biogeochemistry 2005, 72, 315-336. [CrossRef]

106. Eclesia, R.P.; Jobbagy, E.G.; Jackson, R.B.; Biganzoli, F.; Piñeiro, G. Shifts in soil organic carbon for plantation and pasture establishment in native forests and grasslands of South America. Glob. Chang. Biol. 2012, 18, 3237-3251. [CrossRef] [PubMed]

107. Stahl, C.; Freycon, V.; Fontaine, S.; Dezécache, C.; Ponchant, L.; Picon-Cochard, C.; Klumpp, K.; Soussana, J.-F.; Blanfort, V. Soil carbon stocks after conversion of Amazonian tropical forest to grazed pasture: Importance of deep soil layers. Reg. Environ. Chang. 2016, 16, 2059-2069. [CrossRef]

108. Navarrete, D.; Sitch, S.; Aragão, L.E.; Pedroni, L. Conversion from forests to pastures in the Colombian Amazon leads to contrasting soil carbon dynamics depending on land management practices. Glob. Chang. Biol. 2016, 22, 3503-3517. [CrossRef]

109. Elmore, A.J.; Asner, G.P. Effects of grazing intensity on soil carbon stocks following deforestation of a Hawaiian dry tropical forest. Glob. Chang. Biol. 2006, 12, 1761-1772. [CrossRef]

110. Berthrong, S.T.; Jobbágy, E.G.; Jackson, R.B. A global meta-analysis of soil exchangeable cations, pH, carbon, and nitrogen with afforestation. Ecol. Appl. 2009, 19, 2228-2241. [CrossRef]

111. Parfitt, R.; Ross, D. Long-term effects of afforestation with Pinus radiata on soil carbon, nitrogen, and $\mathrm{pH}$ : A case study. Soil Res. 2011, 49, 494-503. [CrossRef]

112. Hewitt, A.; Forrester, G.; Fraser, S.; Hedley, C.; Lynn, I.; Payton, I. Afforestation effects on soil carbon stocks of low productivity grassland in New Zealand. Soil Use Manag. 2012, 28, 508-516. [CrossRef]

113. Bremer, L.L.; Farley, K.A.; Chadwick, O.A.; Harden, C.P. Changes in carbon storage with land management promoted by payment for ecosystem services. Environ. Conserv. 2016, 43, 397-406. [CrossRef] 
114. Cleveland, C.C.; Houlton, B.Z.; Smith, W.K.; Marklein, A.R.; Reed, S.C.; Parton, W.; Del Grosso, S.J.; Running, S.W. Patterns of new versus recycled primary production in the terrestrial biosphere. Proc. Natl. Acad. Sci. USA 2013, 110, 12733-12737. [CrossRef] [PubMed]

115. Bowden, R.D.; Davidson, E.; Savage, K.; Arabia, C.; Steudler, P. Chronic nitrogen additions reduce total soil respiration and microbial respiration in temperate forest soils at the Harvard Forest. For. Ecol. Manag. 2004, 196, 43-56. [CrossRef]

116. Fontaine, S.; Bardoux, G.; Abbadie, L.; Mariotti, A. Carbon input to soil may decrease soil carbon content. Ecol. Lett. 2004, 7, 314-320. [CrossRef]

117. Kirschbaum, M.U.; Guo, L.B.; Gifford, R.M. Why does rainfall affect the trend in soil carbon after converting pastures to forests? A possible explanation based on nitrogen dynamics. For. Ecol. Manag. 2008, 255, 2990-3000. [CrossRef]

118. Piñeiro, G.; Paruelo, J.M.; Jobbágy, E.G.; Jackson, R.B.; Oesterheld, M. Grazing effects on belowground C and $\mathrm{N}$ stocks along a network of cattle exclosures in temperate and subtropical grasslands of South America. Glob. Biogeochem. Cycles 2009, 23. [CrossRef]

119. Smith, K.; Chambers, B. Utilizing the nitrogen content of organic manures on farms-Problems and practical solutions. Soil Use Manag. 1993, 9, 105-111. [CrossRef]

120. Schipper, L.A.; Parfitt, R.; Ross, C.; Baisden, W.T.; Claydon, J.; Fraser, S. Gains and losses in C and N stocks of New Zealand pasture soils depend on land use. Agric. Ecosyst. Environ. 2010, 139, 611-617. [CrossRef]

121. Hunt, J.E.; Phillips, R.L. Carbon budgets for an irrigated intensively grazed dairy pasture and an unirrigated winter-grazed pasture. Biogeosciences 2016, 13, 2927-2944. [CrossRef]

122. Moinet, G.Y.; Cieraad, E.; Turnbull, M.H.; Whitehead, D. Effects of irrigation and addition of nitrogen fertiliser on net ecosystem carbon balance for a grassland. Sci. Total Environ. 2017, 579, 1715-1725. [CrossRef] [PubMed]

123. Kelliher, F.; West, P.; Moir, J. Soil carbon stock beneath an established irrigated pasture grazed by dairy cattle. N. Z. J. Agric. Res. 2015, 58, 78-83. [CrossRef]

124. Schipper, L.A.; Dodd, M.B.; Pronger, J.; Mudge, P.L.; Upsdell, M.; Moss, R.A. Decadal changes in soil carbon and nitrogen under a range of irrigation and phosphorus fertilizer treatments. Soil Sci. Soc. Am. J. 2013, 77, 246-256. [CrossRef]

125. McNally, S.R.; Laughlin, D.C.; Rutledge, S.; Dodd, M.B.; Six, J.; Schipper, L.A. Root carbon inputs under moderately diverse sward and conventional ryegrass-clover pasture: Implications for soil carbon sequestration. Plant Soil 2015, 392, 289-299. [CrossRef]

126. Houlbrooke, D.; Littlejohn, R.; Morton, J.; Paton, R. Effect of irrigation and grazing animals on soil quality measurements in the North Otago Rolling Downlands of New Zealand. Soil Use Manag. 2008, 24, 416-423. [CrossRef]

127. Ryan, K.C. Vegetation and wildland fire: Implications of global climate change. Environ. Int. 1991, 17, 169-178. [CrossRef]

128. Briggs, J.M.; Knapp, A.K.; Blair, J.M.; Heisler, J.L.; Hoch, G.A.; Lett, M.S.; McCARRON, J.K. An ecosystem in transition: Causes and consequences of the conversion of mesic grassland to shrubland. AIBS Bull. 2005, 55, 243-254. [CrossRef]

129. Pineiro, G.; Paruelo, J.M.; Oesterheld, M. Potential long-term impacts of livestock introduction on carbon and nitrogen cycling in grasslands of Southern South America. Glob. Chang. Biol. 2006, 12, 1267-1284. [CrossRef]

130. González-Pérez, J.A.; González-Vila, F.J.; Almendros, G.; Knicker, H. The effect of fire on soil organic matter-A review. Environ. Int. 2004, 30, 855-870. [CrossRef]

131. Knicker, H. How does fire affect the nature and stability of soil organic nitrogen and carbon? A review. Biogeochemistry 2007, 85, 91-118. [CrossRef]

132. Wright, A.L.; Hons, F.M.; Rouquette, F.M., Jr. Long-term management impacts on soil carbon and nitrogen dynamics of grazed bermudagrass pastures. Soil Biol. Biochem. 2004, 36, 1809-1816. [CrossRef]

133. Allard, V.; Soussana, J.-F.; Falcimagne, R.; Berbigier, P.; Bonnefond, J.-M.; Ceschia, E.; D’hour, P.; Hénault, C.; Laville, P.; Martin, $\mathrm{C}$. The role of grazing management for the net biome productivity and greenhouse gas budget (CO2, N2O and CH4) of semi-natural grassland. Agric. Ecosyst. Environ. 2007, 121, 47-58. [CrossRef]

134. Schulz, K.; Voigt, K.; Beusch, C.; Almeida-Cortez, J.S.; Kowarik, I.; Walz, A.; Cierjacks, A. Grazing deteriorates the soil carbon stocks of Caatinga forest ecosystems in Brazil. For. Ecol. Manag. 2016, 367, 62-70. [CrossRef] 
135. Medina-Roldán, E.; Paz-Ferreiro, J.; Bardgett, R.D. Grazing exclusion affects soil and plant communities, but has no impact on soil carbon storage in an upland grassland. Agric. Ecosyst. Environ. 2012, 149, 118-123. [CrossRef]

136. Wu, L.; He, N.; Wang, Y.; Han, X. Storage and dynamics of carbon and nitrogen in soil after grazing exclusion in Leymus chinensis grasslands of northern China. J. Environ. Qual. 2008, 37, 663-668. [CrossRef] [PubMed]

137. Lal, R. Analysis of factors affecting rainfall erosivity and soil erodibility. In Proceedings of the International Conference on Soil Conservation and Management in the Humid Tropics, Ibadan, Nigeria, 1975; Greenland, D.J., Lal, R., Eds.; Wiley: Chichester, NY, USA, 1977. ISBN 0471994731.

138. McSherry, M.E.; Ritchie, M.E. Effects of grazing on grassland soil carbon: A global review. Glob. Chang. Biol. 2013, 19, 1347-1357. [CrossRef]

139. Gourley, C.J.; Dougherty, W.J.; Weaver, D.M.; Aarons, S.R.; Awty, I.M.; Gibson, D.M.; Hannah, M.C.; Smith, A.P.; Peverill, K.I. Farm-scale nitrogen, phosphorus, potassium and sulfur balances and use efficiencies on Australian dairy farms. Anim. Prod. Sci. 2012, 52, 929-944. [CrossRef]

140. Van der Hoek, K.W. Nitrogen efficiency in global animal production. In Nitrogen, the Confer-Ns; Elsevier: Amsterdam, The Netherlands, 1998; pp. 127-132. [CrossRef]

141. Powell, J.; Gourley, C.; Rotz, C.; Weaver, D.M. Nitrogen use efficiency: A potential performance indicator and policy tool for dairy farms. Environ. Sci. Policy 2010, 13, 217-228. [CrossRef]

142. Janssen, B.H. Basics of budgets, buffers and balances of nutrients in relation to sustainability of agroecosystems. In Nutrient Disequilibria in Agroecosystems: Concepts and Case Studies; Smaling, E.M.A., Oenema, O., Fresco, L.O., Eds.; CABI: Oxon, UK, 1999; pp. 27-56. ISBN 0851992684.

143. Van Noordwijk, M. Nutrient cycling in ecosystems. In Nutrient Disequilibria in Agroecosystems: Concepts and Case Studies; Smaling, E.M.A., Oenema, O., Fresco, L.O., Eds.; CABI Publishing: Wallingford, UK, 1999; pp. 1-26. ISBN 9780851992686.

144. Ledgard, S.; Penno, J.; Sprosen, M. Nitrogen inputs and losses from clover/grass pastures grazed by dairy cows, as affected by nitrogen fertilizer application. J. Agric. Sci. 1999, 132, 215-225. [CrossRef]

145. Ledgard, S.F. Nitrogen cycling in low input legume-based agriculture, with emphasis on legume/grass pastures. Plant Soil 2001, 228, 43-59. [CrossRef]

146. Gong, X.Y.; Chen, Q.; Lin, S.; Brueck, H.; Dittert, K.; Taube, F.; Schnyder, H. Tradeoffs between nitrogen-and water-use efficiency in dominant species of the semiarid steppe of Inner Mongolia. Plant Soil 2011, 340, 227-238. [CrossRef]

147. Buckley, C.; Wall, D.P.; Moran, B.; O’Neill, S.; Murphy, P.N. Farm gate level nitrogen balance and use efficiency changes post implementation of the EU Nitrates Directive. Nutr. Cycl. Agroecosyst. 2016, 104, 1-13. [CrossRef]

148. Sun, G.; Zhu-Barker, X.; Chen, D.; Liu, L.; Zhang, N.; Shi, C.; He, L.; Lei, Y. Responses of root exudation and nutrient cycling to grazing intensities and recovery practices in an alpine meadow: An implication for pasture management. Plant Soil 2017, 416, 515-525. [CrossRef]

149. Xu, S.; Silveira, M.L.; Inglett, K.S.; Sollenberger, L.E.; Gerber, S. Soil microbial community responses to long-term land use intensification in subtropical grazing lands. Geoderma 2017, 293, 73-81. [CrossRef]

150. Field, T.; Ball, P.R.; Theobald, P. Leaching of nitrate from sheep-grazed pastures. Proc. N. Z. Grassl. Assoc. 1985, 46, 209-214.

151. Suter, M.; Connolly, J.; Finn, J.A.; Loges, R.; Kirwan, L.; Sebastià, M.T.; Lüscher, A. Nitrogen yield advantage from grass-legume mixtures is robust over a wide range of legume proportions and environmental conditions. Glob. Chang. Biol. 2015, 21, 2424-2438. [CrossRef]

152. Lüscher, A.; Mueller-Harvey, I.; Soussana, J.-F.; Rees, R.; Peyraud, J.-L. Potential of legume-based grassland-livestock systems in Europe: A review. Grass Forage Sci. 2014, 69, 206-228. [CrossRef]

153. Høgh-Jensen, H.; Schjørring, J.K. Interactions between white clover and ryegrass under contrasting nitrogen availability: $\mathrm{N}_{2}$ fixation, $\mathrm{N}$ fertilizer recovery, $\mathrm{N}$ transfer and water use efficiency. Plant Soil 1997, 197, 187-199. [CrossRef]

154. Tilman, D.; Wedin, D. Plant traits and resource reduction for five grasses growing on a nitrogen gradient. Ecology 1991, 72, 685-700. [CrossRef]

155. Monaghan, R.; Hedley, M.; Di, H.; McDowell, R.; Cameron, K.; Ledgard, S. Nutrient management in New Zealand pastures—recent developments and future issues. N. Z. J. Agric. Res. 2007, 50, 181-201. [CrossRef] 
156. Rufino, M.C.; Tittonell, P.; Van Wijk, M.; Castellanos-Navarrete, A.; Delve, R.; De Ridder, N.; Giller, K. Manure as a key resource within smallholder farming systems: Analysing farm-scale nutrient cycling efficiencies with the NUANCES framework. Livest. Sci. 2007, 112, 273-287. [CrossRef]

157. Rufino, M.C.; Rowe, E.C.; Delve, R.J.; Giller, K.E. Nitrogen cycling efficiencies through resource-poor African crop-livestock systems. Agric. Ecosyst. Environ. 2006, 112, 261-282. [CrossRef]

158. Ojima, D.S.; Schimel, D.; Parton, W.; Owensby, C. Long-and short-term effects of fire on nitrogen cycling in tallgrass prairie. Biogeochemistry 1994, 24, 67-84. [CrossRef]

159. Vitousek, P. Nutrient cycling and nutrient use efficiency. Am. Nat. 1982, 119, 553-572. [CrossRef]

160. Chapin, F.S., III; Vitousek, P.M.; Van Cleve, K. The nature of nutrient limitation in plant communities. Am. Nat. 1986, 127, 48-58. [CrossRef]

161. Li, W.; Cao, W.; Wang, J.; Li, X.; Xu, C.; Shi, S. Effects of grazing regime on vegetation structure, productivity, soil quality, carbon and nitrogen storage of alpine meadow on the Qinghai-Tibetan Plateau. Ecol. Eng. 2017, 98, 123-133. [CrossRef]

162. Zhou, G.; Zhou, X.; He, Y.; Shao, J.; Hu, Z.; Liu, R.; Zhou, H.; Hosseinibai, S. Grazing intensity significantly affects belowground carbon and nitrogen cycling in grassland ecosystems: A meta-analysis. Glob. Chang. Biol. 2017, 23, 1167-1179. [CrossRef]

163. Xu, S.; Silveira, M.L.; Inglett, K.S.; Sollenberger, L.E.; Gerber, S. Effect of land-use conversion on ecosystem C stock and distribution in subtropical grazing lands. Plant Soil 2016, 399, 233-245. [CrossRef]

164. Mudge, P.L.; Kelliher, F.M.; Knight, T.L.; O'connell, D.; Fraser, S.; Schipper, L.A. Irrigating grazed pasture decreases soil carbon and nitrogen stocks. Glob. Chang. Biol. 2017, 23, 945-954. [CrossRef]

(C) 2018 by the authors. Licensee MDPI, Basel, Switzerland. This article is an open access article distributed under the terms and conditions of the Creative Commons Attribution (CC BY) license (http:/ / creativecommons.org/licenses/by/4.0/). 